\title{
Uranium diagenesis in sediments underlying bottom waters with high oxygen content
}

\author{
Jennifer L. Morford ${ }^{\mathrm{a}^{*}}$ \\ William R. Martin ${ }^{\mathrm{b}}$ \\ Caitlin M. Carney $^{\mathrm{a}}$
}

${ }^{\mathrm{a}}$ Franklin \& Marshall College, Department of Chemistry, P.O. Box 3003,
Lancaster, PA USA 17604-3003
${ }^{\mathrm{b}}$ Woods Hole Oceanographic Institution
Marine Chemistry and Geochemistry Department, Woods Hole, MA USA 02543

*Corresponding author: jennifer.morford@fandm.edu phone: (717) 358-4590; fax: (717) 291-4343

Submitted to Geochimica et Cosmochimica Acta, August 10, 2008

Resubmitted to Geochimica et Cosmochimica Acta, January 23, 2009 


\begin{abstract}
We measured $U$ in sediments (both pore waters and solid phase) from three locations on the middle Atlantic Bight (MAB) from the eastern margin of the United States: a northern location on the continental shelf off Massachusetts (OC426, $75 \mathrm{~m}$ water depth), and two southern locations off North Carolina (EN433-1, 647 m water depth and EN433-2, $2648 \mathrm{~m}$ water depth). These sediments underlie high oxygen bottom waters (250-270 $\mu \mathrm{M})$, but become reducing below the sediment-water interface due to the relatively high organic carbon oxidation rates in sediments (EN433-1: $212 \mu \mathrm{mol} \mathrm{C} / \mathrm{cm}^{2} / \mathrm{y}$;

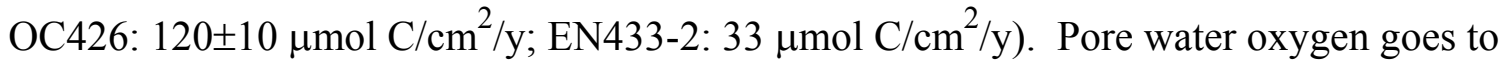
zero by 1.4-1.5 cm at EN433-1 and OC426 and slightly deeper oxygen penetration depths were measured at EN433-2 ( 4 cm).

All of the pore water profiles show removal of $U$ from pore waters. Calculated pore water fluxes are greatest at EN433-1 (0.66 $\left.\pm 0.08 \mathrm{nmol} / \mathrm{cm}^{2} / \mathrm{y}\right)$ and less at EN433-2 and OC426 $\left(0.24 \pm 0.05\right.$ and $0.13 \pm 0.05 \mathrm{nmol} / \mathrm{cm}^{2} / \mathrm{y}$, respectively). Solid phase profiles show authigenic $U$ enrichment in sediments from all three locations. The average authigenic U concentrations are greater at EN433-1 and OC426 (5.8 $\pm 0.7 \mathrm{nmol} / \mathrm{g}$ and $5.4 \pm 0.2 \mathrm{nmol} / \mathrm{g}$, respectively) relative to EN433-2 (4.1 $\pm 0.8 \mathrm{nmol} / \mathrm{g})$. This progression is consistent with their relative ordering of 'reduction intensity', with greatest reducing conditions in sediments from EN433-1, less at OC426 and least at EN433-2. The authigenic $U$ accumulation rate is largest at EN433-1 $\left(0.47 \pm 0.05 \mathrm{nmol} / \mathrm{cm}^{2} / \mathrm{y}\right)$, but the average among the three sites on the MAB is $\sim 0.2 \mathrm{nmol} / \mathrm{cm}^{2} / \mathrm{y}$. Pore water profiles suggest diffusive fluxes across the sediment-water interface that are 1.4-1.7 times greater than authigenic accumulation rates at EN433-1 and EN433-2. These differences are consistent with oxidation and loss of $U$ from the solid phase via irrigation and/or bioturbation, which may compromise the sequestration of $U$ in continental margin sediments that underlie bottom waters with high oxygen concentrations.

Previous literature compilations that include data exclusively from locations where $\left[\mathrm{O}_{2}\right]_{\text {bw }}<150 \mu \mathrm{M}$ suggest compelling correlations between authigenic $\mathrm{U}$ accumulation and organic carbon flux to sediments or organic carbon burial rate.
\end{abstract}


Sediments that underlie waters with high $\left[\mathrm{O}_{2}\right]_{b w}$ have lower authigenic $\mathrm{U}$ accumulation rates than would be predicted from relationships developed from results that include locations where $\left[\mathrm{O}_{2}\right]_{\mathrm{bw}}<150 \mu \mathrm{M}$. 


\section{INTRODUCTION}

Uranium (U) in marine sediments is of particular interest due to its potential use as a paleoproxy to discern changes in reducing conditions in sediments over time. The effectiveness of $U$ as a paleoproxy hinges on our understanding of its geochemical cycling in modern sediments, as defined by the analysis of $U$ in sediments from a range of oceanographic conditions. $\mathrm{U}$ is found in the ocean as a stable $\mathrm{U}(\mathrm{VI})$ carbonate complex and is conservative in ocean waters at a concentration of $14 \mathrm{nmol} / \mathrm{kg}$ (Ku et al., 1977). The primary source of $U$ accumulated in sediments is diffusion across the sediment-water interface into reducing sediments (e.g., Barnes and Cochran, 1990, 1993; Klinkhammer and Palmer, 1991). Removal of $U$ from pore waters has been attributed to microbially-mediated U(VI) reduction to a less soluble U(IV) form (e.g., Lovely et al., 1991; Francis et al., 1994; Tucker et al., 1996; Senko et al., 2002; Sani et al., 2004). U co-precipitation with and adsorption to iron oxide minerals has been seen experimentally (e.g., Hsi and Langmuir, 1985; Duff et al., 2002; Sherman et al., 2008), and U association and cycling with Fe oxides and oxyhydroxides have been observed in marine sediments (e.g., McKee et al., 1987; Barnes and Cochran, 1993; Morford et al., 2007). The net effect of nondiffusive transport (irrigation) on sediment $U$ accumulation is less well understood. Previously accumulated solid phase $\mathrm{U}$ can be released to bottom waters or pore waters via the oxidation of reduced U solid phases (Shaw et al., 1994), which has been shown experimentally to be a fast process (Cochran et al., 1986; Anderson et al., 1989). Authigenic U accumulation appears to be compromised when previously accumulated solid phase $\mathrm{U}$ is oxidized via irrigation that transports oxygen into anoxic sediments (Morford et al., submitted), and/or when bioturbating organisms mix reducing sediments up into the oxic zone (Zheng et al., 2002b). The result is loss of previously accumulated solid phase $\mathrm{U}$ to bottom waters.

$\mathrm{U}$ is also delivered to sediments as particulate non-lithogenic uranium (PNU) that forms in surface ocean waters in conjunction with marine particulate matter and provides a small and variable flux of $U$ to sediments (Anderson, 1982; Klinkhammer and Palmer, 1991; Zheng et al., 2002b). PNU is preserved under low bottom water oxygen concentrations ( $\left[\mathrm{O}_{2}\right]_{\mathrm{bw}}<25 \mu \mathrm{M}$; Anderson, 1982; Zheng et al., 2002b), which suggests 
that down-core records of authigenic $U$ might record changes in organic carbon flux over time (Anderson et al., 1998; Chase et al., 2001; Zheng et al., 2002b; McManus et al., 2006). Highly correlated relationships have been observed between authigenic $U$ and the flux of organic carbon to the sea floor (Anderson et al., 1998; Zheng et al., 2002b; McManus et al., 2005) and carbon burial (McManus et al., 2006). These relationships have been limited, however, by exclusively considering data from locations where $\left[\mathrm{O}_{2}\right]_{b w}$ $<150 \mu \mathrm{M}$ (Zheng et al., 2002a; McManus et al., 2005, 2006).

Insight on the controls of $U$ removal from the aqueous phase, accumulation in the solid phase, and the potential for $U$ remobilization from sediments would provide the necessary context for properly interpreting changes in $U$ accumulation over time. This work includes pore water and solid phase results from several locations with high bottom water oxygen concentrations from the middle Atlantic Bight (MAB). These results, in conjunction with results from other high bottom water oxygen locations, are integrated with earlier compilations to obtain a more complete understanding of $U$ geochemical cycling.

\subsection{Study Sites}

The middle Atlantic Bight (MAB) includes the continental shelf and slope of the northwestern Atlantic Ocean between Cape Cod, Massachusetts $\left(\sim 42^{\circ} \mathrm{N}\right)$ and Cape Hatteras, North Carolina $\left(\sim 34^{\circ} \mathrm{N}\right.$, Figure 1, Table 1). A weak oxygen minimum zone extends from $\sim 600-1200 \mathrm{~m}$ water depth and results in bottom water oxygen concentrations reaching $\sim 140 \mu \mathrm{M}$ at $\sim 800 \mathrm{~m}$ water depth (Zheng et al., 2002a and references therein). Less intense near-bottom currents over the $\sim 500-1000 \mathrm{~m}$ depth range result in the transport of particles to mid-slope depocenters, which are characterized by high organic matter deposition rates (Biscaye et al., 1988; Biscaye and Anderson, 1994) that support high rates of organic carbon remineralization (Jahnke and Jahnke, 2000; Martin and Sayles, 2004).

The 'mud patch' (Bothner et al., 1981) or the 'mud hole' (Santschi et al., 1980) on the northern end of the MAB off Martha's Vineyard is an area noted for its accumulation

of fine-grained sediments in the midst of generally sandy sediments along the continental 
shelf off the eastern United States. This area and the area extending to the southwest have been the focus of previous research (Santschi et al., 1980; Bothner et al., 1981; Rowe et al., 1988; Martin and Sayles, 2004). Our sampling location (Figure 1, OC426, $40^{\circ} 27.6^{\prime} \mathrm{N}, 70^{\circ} 32.7^{\prime} \mathrm{W}, 75 \mathrm{~m}$ water depth) is in the deeper portion of the mud patch. The surface $\sim 2.5 \mathrm{~cm}$ of sediments are rapidly mixed on ${ }^{234} \mathrm{Th}$ timescales and overlay a layer of less rapidly mixed sediments that extends tens of centimeters deeper (Santschi et al., 1980). Mixing coefficients calculated from ${ }^{210} \mathrm{~Pb}$ profiles $\left(0.6-7 \times 10^{-7} \mathrm{~cm}^{2} / \mathrm{s}\right.$; Bothner et al., 1981; Santschi et al., 1980) are at least an order of magnitude greater than those found in the deep sea but lower than those calculated for estuarine sediments (Bothner et al., 1981). Solid phase organic carbon concentrations range from $0.5-1.7 \%$ across the mud patch (Bothner et al., 1981; Rowe et al., 1988). The mass accumulation rate is $24 \pm 7$ $\mathrm{mg} / \mathrm{cm}^{2} / \mathrm{y}$ (Bothner et al., 1981).

The station locations on the southern portion of the MAB (Figure 1, EN433-1: $35^{\circ} 50.927^{\prime} \mathrm{N}, 74^{\circ} 49.462^{\prime} \mathrm{W}, 647$ m water depth; EN433-2: $36^{\circ} 09.184^{\prime} \mathrm{N}, 7^{\circ} 03.343^{\prime} \mathrm{W}$, $2648 \mathrm{~m}$ water depth) are also near sites of extensive analysis (Biscaye and Anderson, 1994; Anderson et al., 1994; Jahnke and Jahnke, 2000; Thomas et al., 2002; Alperin et al., 2002; Zheng et al., 2002a, b). Average particulate fluxes are greater along the southern MAB relative to the northern MAB (Biscaye and Anderson, 1994). Similar differences have been found in organic matter oxidation rates with the southern depocenter oxidation rates 3-6 times larger than rates measured in northern MAB areas (Martin and Sayles, 2004). Organic matter oxidation rates determined using benthic chambers at nearby locations suggest greater oxidation rates in sediments at EN433-1 relative to EN433-2 (260-340 $\mu \mathrm{mol} / \mathrm{cm}^{2} / \mathrm{y}$ versus $94 \mu \mathrm{mol} / \mathrm{cm}^{2} / \mathrm{y}$; Jahnke and Jahnke, 2000). The organic carbon flux measured using sediment traps during SEEP II near $\sim 37^{\circ} \mathrm{N}$ suggested a carbon flux of $200 \mu \mathrm{mol} \mathrm{C} / \mathrm{cm}^{2} / \mathrm{y}$ at $1000 \mathrm{~m}$ water depth (Biscaye and Anderson, 1994), whereas during SYNOP at $\sim 35.5^{\circ} \mathrm{N}$ the carbon flux was $60-180 \mu \mathrm{mol}$ $\mathrm{C} / \mathrm{cm}^{2} / \mathrm{y}$ at $2340-3110 \mathrm{~m}$ water depth (Zheng et al., 2002b and references therein).

\section{METHODS AND ANALYTICAL PROCEDURES}




\subsection{Sampling Methods}

Sediment cores with clearly defined sediment-water interfaces and overlying waters that were clear of resuspended sediment upon recovery were collected using a multicorer during cruises OC426 (June 2006) and EN433 (April 2007). Cores were immediately transferred to a $4^{\circ} \mathrm{C}$ room. All core processing occurred at $4^{\circ} \mathrm{C}$ in a refrigerated van while at sea. The overlying waters were sampled and the cores were then sectioned in nitrogen-filled glove bags. The resolution for the first 16 (EN433) or 24 (OC426) samples was determined by filling scintillation and centrifuge vials. By knowing the volume of the vials and the diameter of the core, the depth sampled was calculated. The first four samples were from intervals of $0.18 \mathrm{~cm}$, and samples 5 to 16 (EN433) or 5 to 24 (OC426) were from depth intervals of $0.31 \mathrm{~cm}$. This sampling method required sampling across the entire surface including the sediment against the core liner; however, sharp metal profiles in these samples suggest minimal profile smearing (see later section). For the sediment cores from EN433, sediment sampling continued for samples 17 to 24 at $0.5 \mathrm{~cm}$ or $1 \mathrm{~cm}$ intervals to the bottom of the core.

Sediments were centrifuged. Pore waters were filtered in a nitrogen-filled glove bag using nitrogen-flushed syringes and $0.45-\mu \mathrm{m}$ filters and sampled for trace metals and nutrients. Nutrient samples were transferred to vials that had previously been rinsed with $18 \mathrm{M} \Omega$ MilliQ water (MQ) and dried in a laminar flow bench. Trace metal samples were transferred to 4-mL acid-cleaned HDPE bottles that were pre-spiked with $40 \mu \mathrm{L}$ of concentrated Optima-grade nitric acid (Fisher). Prior to the cruise, syringes and filters for trace metal sampling were cleaned with $2 \mathrm{M} \mathrm{HCl}$, rinsed with MQ water, and dried in a laminar flow bench. Sample storage 4-mL HDPE bottles were filled with $2 \mathrm{M} \mathrm{HCl}$, heated for four days at $60^{\circ} \mathrm{C}$, rinsed with $\mathrm{MQ}$, and dried in a laminar flow bench prior to the cruise.

Additional cores were retrieved for porosity (EN433-1, EN433-2, OC426) and resistivity (OC426 only). Porosity and resistivity are used to constrain sedimentary diffusion coefficients (McDuff and Ellis, 1979) as described in Martin et al. (1991). To obtain high-resolution pore water oxygen and nutrient profiles, an additional core underwent whole-core squeezing at each location. 


\subsection{Analytical Procedures}

Precision was determined by analyzing triplicate bottom water samples. Pore water nutrients were determined with a precision of $\leq 4 \%$ by autoanalyzer using methods adapted from Glibert and Loder (1977). Pore water $\mathrm{O}_{2}$ profiles were determined by the method of Martin et al., 1991. The $\mathrm{O}_{2}$ electrode used for the measurements was calibrated at each site with small-volume Winkler titrations (precision $\pm 3 \%$ ).

All pore water and solid phase U samples were analyzed using a Finnigan ELEMENT II high-resolution inductively coupled plasma-mass spectrometer (ICP-MS) at the Woods Hole Oceanographic Institution. Separate aliquots of the pore water and solid phase digest samples were analyzed for Al, Fe and Mn using a Spectro Ciros CCD ICP-optical emission spectrometer (ICP-OES) at Franklin \& Marshall College. The ICPOES wavelengths for quantification were $396.152 \mathrm{~nm}, 275.573 \mathrm{~nm}, 239.562 \mathrm{~nm}$ and $260.569 \mathrm{~nm}$ for $\mathrm{Al}$, solid phase Fe, pore water Fe, and Mn, respectively. To determine accuracy and precision for the pore water $U$ samples, replicate measurements were made of overlying water samples and CASS-4 (Nearshore Seawater Reference Material for Trace Metals, National Research Council Canada). Spiked CASS-4 samples were analyzed to determine the precision and accuracy of Fe and Mn at the expected concentration levels. Replicate measurements of PACS-2 (Marine Sediment Reference Materials for Trace Metals and other Constituents, National Research Council Canada) were used to assess accuracy and precision of the solid phase digest samples. Replicate measurements of dissolved solid phase samples provided a further assessment of precision.

$\mathrm{U}$ concentrations were measured using isotope dilution $\left({ }^{236} \mathrm{U}\right)$. Average bottom water concentrations (Table 2, EN433-1: $13.2 \pm 0.2 \mathrm{nmol} / \mathrm{kg}$; EN433-2: $13.07 \pm 0.05$ $\mathrm{nmol} / \mathrm{kg}$; OC426: $12.3 \mathrm{nmol} / \mathrm{kg}$ ) are $6 \%$ lower than the expected seawater concentration of $14 \mathrm{nmol} / \mathrm{kg}$ (Ku et al., 1977) after adjusting for slight differences in salinity (this work: EN433-1, 34.98; EN433-2, 34.91; Bacon et al. (1994): OC426, 33.4). Although the CASS-4 standard is not certified for $U$, the information value of $12 \mathrm{nmol} / \mathrm{kg}$ is similar to the average measured concentration $(11.8 \pm 0.6 \mathrm{nmol} / \mathrm{kg} ; \mathrm{n}=8)$, with a precision of $\leq 5 \%$. 
$\mathrm{Mn}$ and $\mathrm{Fe}$ were quantified by external calibration curve and an internal standard of scandium was added to each sample to correct for instrument deviations during analysis. Since the CASS-4 standard has extremely low Mn and Fe concentrations, an aliquot of this standard was spiked with additional Fe and $\mathrm{Mn}$ to $\sim 40 \mu \mathrm{mol} / \mathrm{kg}$ and analyzed. The measured concentrations of the spiked CASS- 4 standard were within $8 \%$ of the expected concentration and the precision was $\leq 5 \%$ for both $\mathrm{Mn}$ and $\mathrm{Fe}(\mathrm{n}=5)$. Due to the larger sample requirements for ICP-OES, replicate pore water samples were not analyzed for $\mathrm{Mn}$ and Fe.

The solid sample remaining after centrifugation was freeze-dried and ground for solid phase analyses. Dried solid phase samples were completely dissolved using a modification of the method of Murray and Leinen (1993) as described in Morford and Emerson (1999), which included concentrated $\mathrm{HF}, \mathrm{HCl}, \mathrm{HNO}_{3}$ and $30 \% \mathrm{H}_{2} \mathrm{O}_{2}$. All of the acids for solid phase dissolution were trace-metal grade and the peroxide was A.C.S. grade, except for the acid used for the final dilution (Fisher, OmniTrace Ultra High Purity nitric acid). The average measured concentrations of the PACS-2 standard were within the $95 \%$ confidence level for $\mathrm{Al}$ and $\mathrm{Mn}$, and $\sim 6 \%$ low for Fe (Table 3 ). The average $\mathrm{U}$ concentration was lower than the value given for PACS-2, although this value is not certified. However, the average measured $U$ concentration is consistent with previous determinations (Table 3). The precision for replicate analyses of PACS-2 was $\leq 4 \%$ for $\mathrm{U}, \mathrm{Al}, \mathrm{Fe}$ and $\mathrm{Mn}(\mathrm{n}=6)$, which was consistent with the reproducibility of duplicate measurements of solid phase digests (U, 5 sets of duplicates; Al, Fe and Mn, 6 sets of duplicates; Table 4).

Excess ${ }^{234} \mathrm{Th}$ and ${ }^{210} \mathrm{~Pb}$ were analyzed by direct counting on Canberra LeGe detectors (Sayles et al., 2001). Porosity and resistivity were determined by the methods of Manheim et al. (1974) and Andrews and Bennett (1981), respectively, using procedures described previously (Martin and Sayles, 2004). Solid phase organic carbon content was determined using a Carlo Erba Elemental Analyzer (Model 1108).

\section{RESULTS}

\subsection{Sedimentary conditions at the EN433 and OC426 sites}


It is necessary to characterize the sedimentary conditions in order to properly interpret the pore water and solid phase $U$ profiles and to adequately compare $U$ diagenesis among locations. Sedimentary conditions that appear to exert control over trace metal mobility include bottom water oxygen concentration, oxygen penetration depth, sedimentary Mn and Fe cycling, depth of bioturbation and the rate of organic matter oxidation (e.g., Aller 1990, 1994; Barnes and Cochran, 1993; Canfield et al., 1993; Crusius et al., 1996; Zheng et al., 2000, 2002b; McManus et al., 2005; Morford et al., 2007). Therefore, in order to provide the necessary context for our discussion of $U$ diagenesis, we will first discuss and compare the conditions among these MAB locations.

\subsubsection{Oxygen, nutrient, manganese and iron profiles}

Bottom waters contain high concentrations of oxygen $(247 \mu \mathrm{M}$ at EN433-1; 270 $\mu \mathrm{M}$ at EN433-2 and OC426). Pore water oxygen concentrations decrease smoothly with depth below the sediment-water interface reaching near-zero concentrations at $1.4-1.5 \mathrm{~cm}$ at EN433-1 and OC426 and $\sim 4 \mathrm{~cm}$ at EN433-2, as determined by the apparent inflection in the nitrate profile and the assumption that the start of denitrification coincides with oxygen going to zero in the sediments (Figure 2). Following the expected sequence of oxidant depletion during organic carbon oxidation (Froelich et al., 1979), nitrate and nitrite consumption in pore waters begins by $\sim 1 \mathrm{~cm}$ at EN433-1 and OC426. At the EN433-2 site, where the oxygen penetration depth is deepest, nitrification is apparent in the oxic zone followed by denitrification and consumption of nitrate by $\sim 4 \mathrm{~cm}$. Pore water ammonium, which is indicative of anaerobic organic carbon degradation via iron and sulfate reduction (Reimers et al., 1992), increases at all sites with depth. Pore water ammonium increases linearly to $\sim 550 \mu \mathrm{M}$ and $\sim 80 \mu \mathrm{M}$ at EN433-1 and OC426, respectively. At EN433-2, pore water ammonium concentrations start increasing below the denitrification zone and increase to $\sim 25 \mu \mathrm{M}$ by $8 \mathrm{~cm}$. The ammonium maximum near the sediment-water interface at EN433-2 is most likely an artifact of shipboard core sectioning and centrifugation and has been previously discussed (Martin and Sayles, 2004). 
Pore water and solid phase $\mathrm{Mn}$ and Fe profiles also suggest clear differences in sedimentary reducing conditions. The peak pore water Mn concentration appears at $\sim 1$ cm at EN433-1 and progressively deeper at OC426 and EN433-2 (Figure 2). The deeper appearance of pore water Mn at EN433-2, coupled with the deeper oxygen penetration, allows for the oxidation of upwards diffusing $\mathrm{Mn}^{2+}$ and the precipitation of $\mathrm{Mn}$ oxides in surface sediments extending $\sim 5 \mathrm{~cm}$ below the sediment-water interface (Figure 3 ). There are $\sim 60 \%$ and $\sim 20 \%$ solid phase Mn enrichments at the sediment-water interface at EN433-1 and OC426, respectively, suggesting the formation of much smaller Mn oxide caps in surface sediments from these locations and probable diffusion of $\mathrm{Mn}^{2+}$ from sediments to overlying water.

Consistent with the expected ordering of oxidants, the Fe pore water profiles have peak concentrations at deeper depths relative to the $\mathrm{Mn}$ pore water peaks. The peak in $\mathrm{Fe}$ concentration is found at 1.7-2.9 cm at EN433-1, and increasingly deeper at OC426 and EN433-2, respectively. The decrease in pore water Fe concentrations to below detection limits $(\mathrm{DL}=2 \mu \mathrm{M})$ at 7 to $9 \mathrm{~cm}$ in profiles from EN433-1 and OC426 suggest $\mathrm{Fe}^{2+}$ removal via precipitation of $\mathrm{FeS}$ phases in sediments. This is consistent with the relatively greater pore water ammonium concentrations and the greater importance of anaerobic organic carbon degradation via sulfate reduction at these sites (see next section). The solid phase Fe concentrations are relatively constant, and there is no discernable solid phase Fe enrichment in surface sediments relative to deeper sediments. This observation is expected due to the relatively high detrital Fe concentration in the solid phase relative to the upwards Fe flux calculated from the pore water profiles, which would make Fe enrichments in surface sediments difficult to measure (see next section).

\subsubsection{Fluxes for determining total organic carbon oxidation, burial and rain rates}

To determine the organic carbon oxidation rates in sediments at each location, the pore water data is modeled with linear $\left(\mathrm{NO}_{3}+\mathrm{NO}_{2}, \mathrm{Mn}^{2+}\right.$ and $\mathrm{Fe}^{2+}$ profiles; $\mathrm{NH}_{4}{ }^{+}$at EN433-2, OC426) or exponential $\left(\mathrm{O}_{2}\right.$ profiles; $\mathrm{NH}_{4}{ }^{+}$at EN433-1) fits. Linear gradients are typically taken between two or three data points and represent the steepest portion of 
the pore water profile (Figure 2). The exponential fit for the pore water oxygen and $\mathrm{NH}_{4}{ }^{+}$(EN433-1 only) profiles extend over the top 1 to $2 \mathrm{~cm}$ of sediments. Nutrient and oxygen fluxes are calculated as:

$$
\text { Flux }=-\phi D_{\text {sed }} \frac{d C}{d x}
$$

The porosity $(\phi)$ was determined at each location (Figure 4) and the depth interval over which the gradient is determined $(\mathrm{dC} / \mathrm{dx})$ is identified in Figure 2. Each solute's diffusion coefficient $\left(\mathrm{D}_{\mathrm{sw}}\right)$ is calculated at the in situ temperature and corrected for dynamic viscosity (Li and Gregory, 1974; Boudreau, 1997). The effect of sediment tortuosity $\left(\theta^{2}\right)$ on the diffusion coefficient for seawater $\left(D_{\mathrm{sw}}\right)$ is experimentally determined at OC426 where both resistivity and porosity were measured (Figure 4). The ratio of sediment resistivity to pore water resistivity is equivalent to the formation factor, F (McDuff and Ellis, 1979), and is used to calculate the diffusion coefficient in sediments $\left(D_{\text {sed }}\right)$ :

$$
D_{\text {sed }}=\frac{D_{\text {sw }}}{\theta^{2}}=\frac{D_{\text {sw }}}{\phi F}=D_{\text {sw }} \phi^{v-1}
$$

At sites EN433-1 and EN433-2, where resistivity measurements are not available, the tortuosity is approximated from the porosity data as described in Boudreau (1997):

$$
\theta^{2}=1-\ln \left(\phi^{2}\right)
$$

The total amount of organic matter oxidized in sediments was calculated as the sum of the individual oxidant fluxes, accounting for their relative stoichiometries (Reimers et al., 1992). Sulfate reduction rates were estimated by modeling the ammonium profiles. Oxygen and sulfate were quantitatively the most important oxidants at EN433-2 and EN433-1, respectively, whereas and oxygen and sulfate reduction were of similar importance at OC426 (Table 5). Denitrification accounted for $\sim 7-8 \%$ of organic matter oxidation at these sites, while manganese and iron reduction accounted for $\leq 1.5 \%$. The sum of these processes suggests that the rate of organic carbon oxidation in sediments was greatest at EN433-1, 40\% less at OC426 and $\sim 84 \%$ less at EN433-2. Our measured organic carbon oxidation rates at the EN433 sites, $33-212 \mu \mathrm{mol} / \mathrm{cm}^{2} / \mathrm{y}$, are 
$\sim 20-60 \%$ lower than those measured previously in this area $\left(94-260 \mu \mathrm{mol} / \mathrm{cm}^{2} / \mathrm{y}, \mathrm{Jahnke}\right.$ and Janhke, 2000).

Solid phase organic carbon concentrations $\left(\left[\mathrm{C}_{\mathrm{org}}\right]\right)$ are greatest at EN433-1 $(2.7 \pm 0.2 \%$, Figure 3$)$, less at OC426 ( 1.5\%, Bothner et al., 1981) and least at EN433-2 $(0.89 \pm 0.09 \%$, Figure 3$)$. The average measured $\left[\mathrm{C}_{\text {org }}\right]$ at EN433-1 is similar to measurements made at nearby locations from similar water depths (750 m, 2.4-3.1\%, Alperin et al., 1999, 2002; 600-630 m, 2.2-2.7\%, Thomas et al., 2002). The organic carbon burial rates are calculated from the solid phase organic carbon concentrations and mass accumulation rate (MAR) as:

$$
\mathrm{C}_{\text {burial }}=\left[\mathrm{C}_{\text {org }}\right] \mathrm{MAR}
$$

The organic matter rain rates are calculated as the sum of the organic carbon burial rate and the organic carbon oxidation rate and were 410,160 and $58 \mu \mathrm{mol} / \mathrm{cm}^{2} / \mathrm{y}$ at EN433-1, OC426 and EN433-2, respectively. The organic carbon flux at EN433-2 is similar to that

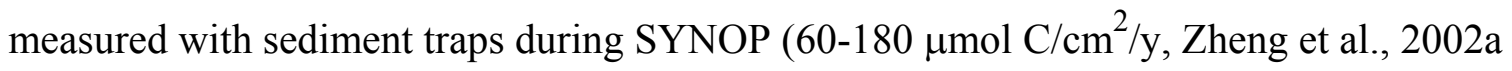
and references therein). The carbon fluxes to sediments measured at the SEEP-II sites using sediment traps at similar water depths $\left(200 \mu \mathrm{mol} \mathrm{C} / \mathrm{cm}^{2} / \mathrm{y}\right.$; Biscaye and Anderson, 1994) are less than either the calculated organic carbon rain rate or the measured carbon oxidation rate in sediments closer to the EN433-1 site. The carbon flux to sediments at EN433-1 should be at least greater than the measured organic carbon oxidation rates

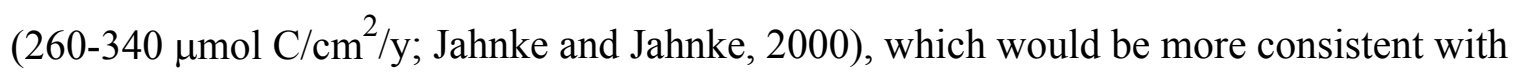
our calculated organic matter rain rate of $410 \mu \mathrm{mol} / \mathrm{cm}^{2} / \mathrm{y}$.

\subsubsection{Bioturbation}

Both ${ }^{234} \mathrm{Th}$ and ${ }^{210} \mathrm{~Pb}$ are useful for determining the extent of bioturbation in these sediments, and their different half-lives ( $24 \mathrm{~d}$ vs. $22 \mathrm{y}$, respectively) provide some indication regarding the timeframe of mixing. Profiles of excess ${ }^{234}$ Th suggest that surface sediments are rapidly mixed at both EN433-1 and EN433-2 (Figure 5). Therefore a sedimentary constituent with a mean lifetime of $\sim 1$ month can be transported $\sim 1-2 \mathrm{~cm}$ 
by bioturbation. At the EN433-1 site, the solid phase ${ }^{210} \mathrm{~Pb}$ profile shows a well-defined mixed layer extending $\sim 8 \mathrm{~cm}$, and excess ${ }^{210} \mathrm{~Pb}$ is present to $\sim 12 \mathrm{~cm}$. Excess ${ }^{210} \mathrm{~Pb}$ is present down to $\sim 11 \mathrm{~cm}$ at EN433-2, although the amount is not constant. Mixing over the top $10-15 \mathrm{~cm}$ has been previously observed in sediments from the MAB along the SEEP-I transect $\left(\sim 71^{\circ} \mathrm{W}\right.$; Anderson et al., 1988). A subsurface peak in ${ }^{210} \mathrm{~Pb}$ from $10-12$ $\mathrm{cm}$ is also apparent at EN433-2 and is not uncommon in sediments from the MAB (Anderson et al., 1988). This subsurface peak may suggest transport of material from the surface to this depth horizon. Therefore in addition to bioturbation, we expect non-local mixing of solid phase material from the surface to the deeper portion of the mixed layer at EN433-2.

\subsection{Uranium}

\subsubsection{U pore water profiles and fluxes}

All of the pore water profiles show removal of $U$ from pore waters (Figure 2). A steep gradient in pore water $U$ is apparent in sediments from EN433-1 and is coincident with the peak in pore water Fe (Figure 2). The pore water U gradients for OC426 and EN433-2 are less steep, although scatter in the OC426 pore water U profile makes it difficult to discern whether the gradient extends from 0 to $4 \mathrm{~cm}$ or for the entire length of the sediment core. The pore water $U$ concentrations continually decrease over the entire core length at the EN433-2 site. The average minimum pore water U concentration deeper than $5 \mathrm{~cm}$ at EN433-1 is $2.9 \pm 0.5 \mathrm{nmol} / \mathrm{kg}$, which is similar to the pore water $\mathrm{U}$ concentration reached at $20 \mathrm{~cm}$ at EN433-2 (2.6 nmol/kg; Table 2). The minimum pore water U concentrations at the EN433 sites are similar to those measured in other cores recovered from the southern portion of the MAB ( $\sim 2 \mathrm{nM}$; Zheng et al., 2002a). The minimum pore water $\mathrm{U}$ concentration reached at the bottom of the OC426 sediment core is $\sim 6 \mathrm{nmol} / \mathrm{kg}$. We don't know if a lower pore water $U$ concentration might have been reached if the core from OC426 had been longer than its recovered length of $\sim 13 \mathrm{~cm}$; however, $\mathrm{U}$ concentrations appear to still be decreasing with increasing depth in sediments. 
The pore water $\mathrm{U}$ concentrations $\left([\mathrm{U}]_{\mathrm{x}}\right.$, Figure 2$)$ are modeled with depth below the sediment-water interface, $\mathrm{x}$, following McManus et al. (2005) as:

$$
[U]_{x}=M_{1}\left(1-e^{\left(-M_{2} x\right)}\right)+[U]_{b w} e^{\left(-M_{2} x\right)}
$$

Parameters solved as part of the model fit for $U$ include $M_{1}(\mathrm{nmol} / \mathrm{kg}), \mathrm{M}_{2}\left(\mathrm{~cm}^{-1}\right)$ and the bottom water $U$ concentration $\left([U]_{b w}, \mathrm{nmol} / \mathrm{kg}\right.$; Table 6$)$. To optimize the fit near the sediment-water interface, the model is fit to the top $8 \mathrm{~cm}, 4 \mathrm{~cm}$ and $13 \mathrm{~cm}$ at EN433-1, EN433-2 and OC426, respectively (Figure 2). The U flux across the sediment-water interface $\left(\right.$ Flux $\left._{U}\right)$ is calculated as described in McManus et al. (2005):

$$
\operatorname{Flux}_{\mathrm{U}}=-\phi \mathrm{D}_{\mathrm{sed}} \mathrm{M}_{2}\left(\mathrm{M}_{1}-[\mathrm{U}]_{\mathrm{bw}}\right)
$$

The diffusion coefficient in seawater for $U$ is assumed to be equivalent to that of Mo, since the diffusion of an anionic $U$ carbonate complex is expected to approximate that of anionic molybdate more closely than the Li and Gregory (1974) value for $\mathrm{UO}_{2}{ }^{2+}$. The diffusion coefficient was then corrected for sediment tortuosity as described above. The uncertainty in the parameters $\mathrm{M}_{1}, \mathrm{M}_{2}$ and $[\mathrm{U}]_{\mathrm{bw}}$ are propagated to determine an uncertainty for the flux estimate; however, this calculated uncertainty does not include the uncertainty in the diffusion coefficient and therefore should be considered a minimum value (McManus et al., 2005).

The calculated pore water $U$ flux into sediments at EN433-1 is $\sim 3$ times larger than EN433-2 and $\sim 5$ times larger than OC426 (Table 6). However, the relative uncertainty in the calculated flux for OC426 is larger than the relative uncertainties for the other two fluxes and reflects the additional difficulty in fitting the more scattered pore water data at this location.

\subsubsection{U solid phase profiles and fluxes}

Measured solid phase $\mathrm{U}$ concentrations are presented as U/Al ratios, and at all three locations the U/Al ratios increase with depth (Figure 3). Authigenic enrichment is evident when the profiles are compared to the estimated detrital U/Al ratio $\left(2.8 \times 10^{-6}\right.$; Turekian and Wedepohl, 1961; Taylor and McLennan, 1985), and the authigenic 
concentration is quantified from the average concentrations deeper than $9 \mathrm{~cm}$ (see notes in Table 7). Considering the variability of the sediment concentrations, the authigenic concentrations at EN433-1 and OC426 are greater than the authigenic concentration calculated for EN433-2.

The authigenic $U$ accumulation rate $\left(U_{A c c}\right)$ is calculated in a similar manner as the organic carbon burial rate. The largest $\mathrm{U}_{\mathrm{Acc}}$ is measured at EN433-1 and equivalent solid phase accumulation rates are measured at EN433-2 and OC426. The measured authigenic $\mathrm{U}$ accumulation rate at EN433-2 is similar to those previously measured from the southern MAB (0.084-0.29 nmol $/ \mathrm{cm}^{2} / \mathrm{y}^{1}$; Zheng et al., 2002a). The solid phase U accumulation rates are less than the calculated pore water $U$ fluxes at the EN433 sites by a factor of 1.4-1.7, while the measured accumulation rates is identical to the calculated pore water flux at OC426.

\section{DISCUSSION}

\subsection{Sedimentary conditions}

Considering the oxygen penetration depths and pore water profiles for nitrate, ammonium, $\mathrm{Fe}$ and $\mathrm{Mn}$, it is possible to determine a relative ordering of reducing conditions in the sediments, with greater 'reduction intensity' reflected by shallower oxygen penetration, shallower consumption of nitrate, greater ammonium concentrations at depth, and shallower first appearances of $\mathrm{Mn}$ and Fe in pore waters. This comparison suggests that the 'reduction intensity' is greatest at EN433-1, less at OC426 and least at EN433-2. This comparison can be further extended to include other sites with high bottom water oxygen concentrations, such as Hingham and Buzzards bays (Morford et al., 2007; Morford et al., submitted). Both bays have high bottom water oxygen concentrations coupled with high carbon oxidation and burial rates (Table 8). This combination results in oxygen penetration depths below the sediment-water interface that are less than one centimeter. At Hingham Bay, pore water ammonium increases to 2000 $\mu \mathrm{M}$, and pore water sulfide is present below $7 \mathrm{~cm}$ (Morford et al., 2007). However, at the Buzzards Bay site ammonium concentrations only increase to $\sim 160 \mu \mathrm{M}$ and pore water 
sulfide concentrations remain below the detection limit $(\sim 2 \mu \mathrm{M})$ down to $\sim 25 \mathrm{~cm}$

(Morford et al., submitted). A composite ordering of 'reduction intensity' in sediments from greatest to least is:

$$
\text { Hingham Bay }>\text { EN433-1 }>\text { Buzzards Bay }>\text { OC426 }>\text { EN433-2 }
$$

\section{2. $\mathrm{U}$ geochemical cycling in sediments underlying oxic bottom waters}

The progression of authigenic $U$ accumulation is similar to our expectations based on 'reduction intensity'. The largest $U$ accumulation occurs at Hingham Bay, where sedimentary conditions are the most reducing (Table 7). Benthic chamber fluxes in excess of diffusive fluxes across the sediment-water interface have suggested that irrigation augments the accumulation of $U$ in sediments at the Hingham Bay site (Morford et al., 2007). Authigenic U accumulation is less in sediments from EN433-1 and Buzzards Bay, and least at OC426 and EN433-2. The net effect of irrigation at these four locations may be to decrease the accumulation of $U$. Previous research has shown that bioturbation (Zheng et al., 2002a) and/or irrigation (Morford et al., submitted) can compromise authigenic $U$ accumulation in sediments by resulting in oxidative loss of $U$ to overlying waters. Earlier work on the MAB suggested variable remobilization of $U$ from sediments; the observed variability may have been due to the low sampling resolution of the pore water $U$ profiles (Zheng et al., 2002a). Higher resolution pore water profiles from Buzzards Bay (Morford et al., submitted) and the southern MAB locations suggest diffusive U fluxes into sediments that are greater than the measured solid phase authigenic $U$ accumulation rates. The difference between the pore water fluxes and solid phase accumulation rates may be due to oxidation and loss of $U$ from the solid phase.

There are several sources of evidence for irrigation and bioturbation at these sites that would be expected to enhance oxidative loss of $U$ from sediments. Significant rates of irrigation are inferred from the comparisons of calculated diffusive fluxes with measured benthic chamber fluxes near the southern MAB locations (Jahnke and Jahnke, 2000). Our solid phase ${ }^{234} \mathrm{Th}$ and ${ }^{210} \mathrm{~Pb}$ profiles show that mixing is evident into the anoxic sediment zone at the EN433 sites. Although the calculated pore water flux and 
measured solid phase accumulation rate at OC426 are the same and imply little/no oxidative loss of $\mathrm{U}$ from the sediments, the greater uncertainty in the pore water flux due to the complexity of the pore water profile hampers this interpretation. Bromide and ${ }^{222} \mathrm{Rn}$ tracers show that sediment irrigation and enhanced solute transport between seawater and sediments are important processes at locations in the northern MAB at $<$ $500 \mathrm{~m}$ water depth (Martin and Sayles, 2004). Oxygen exposure of U-containing anoxic sediments is likely in sediments along the MAB. This work emphasizes the importance of continental margin sediments as a sink for $\mathrm{U}$; however, the extent of its importance to the global mass balance of $\mathrm{U}$ may be tempered by oxidative loss of previously accumulated solid phase $\mathrm{U}$.

\subsection{Relationships with organic carbon and oxygen penetration depth}

Compelling correlations have been observed between authigenic $U$ accumulation and organic carbon flux to sediments (Zheng et al., 2002a; McManus et al., 2005, 2006) and organic carbon burial rate (McManus et al., 2005, 2006). When sites off Washington/Oregon states (Morford et al., 2005; Table 8) are also included, similar relationships are observed (Figure 6). These results have been used to suggest that the reactions that govern authigenic $\mathrm{U}$ accumulation are primarily sensitive to the delivery and burial of organic carbon (McManus et al., 2006). However, these conclusions have been based on results from locations where bottom water oxygen concentrations do not exceed $150 \mu \mathrm{M}$.

The incorporation of data from sediments that underlie high $\left[\mathrm{O}_{2}\right]_{b w}$ casts doubt on these relationships. Results from sites with high $\left[\mathrm{O}_{2}\right]_{\mathrm{bw}}$ from the Laurentian Trough on the eastern Canadian continental margin (Sundby et al., 2004), the MAB (Zheng et al., 2002a; this work), Hingham Bay (Morford et al., 2007) and Buzzards Bay (Morford et al., submitted) show no universal relationship between authigenic $\mathrm{U}$ accumulation and organic carbon burial rate (Figure 6A). Although some of these additional locations continue to fall on the linear relationship based on low $\left[\mathrm{O}_{2}\right]_{\mathrm{bw}}$ sites, the locations with greater 'reduction intensity' (Hingham and Buzzards bays, EN433-1 and the most 
reducing site from the Laurentian Trough) fall along a different trend. This other trend shows lower authigenic $\mathrm{U}$ accumulation rates than would be predicted from the trend based on low $\left[\mathrm{O}_{2}\right]_{\mathrm{bw}}$ sites.

Currently, there is no known direct mechanistic rationale for a linear relationship between organic carbon burial and authigenic accumulation of $U$. The organic carbon buried in sediments is the remnant after the more labile fraction of organic carbon has been oxidized, with the oxidized portion dictating the extent of reducing conditions in sediments. The organic carbon that remains would not be expected to control the extent of reducing conditions within the top $20 \mathrm{~cm}$ of sediments where authigenic $\mathrm{U}$ accumulation is measured. Although we have plotted the authigenic $U$ accumulation rate versus the organic carbon burial rate (McManus et al., 2006), we could have plotted the authigenic $U$ concentration versus the organic carbon concentration since the mass accumulation rate is inherently the same for the two variables. Correlations between $U$ and organic carbon concentrations are more likely a result of common dilution by other detrital phases present in sediments. Earlier research in Saanich Inlet showed a strong correlation between $U$ and organic carbon concentrations in sediments (Kolodny and Kaplan, 1973). Further investigation suggested that the variable supply of detrital particles controlled the organic carbon distribution in Saanich Inlet sediments (François, 1988), so that the correlation between the $U$ and organic carbon concentrations was more likely due to common dilution by detrital phases (Anderson et al., 1989). In addition, Anderson et al. (1989) showed that $U$ and organic carbon were weakly correlated in trap material, further suggesting that accumulation of $U$ in sediments was not primarily due to its association with particulate organic matter. Therefore, a linear relationship between authigenic $U$ and organic carbon concentrations could be related to factors unassociated with the mechanism(s) of $U$ accumulation.

The authigenic $U$ accumulating in sediments is thought to be a direct result of the reducing conditions and the microbially mediated pathways that result in $U(V I)$ reduction (e.g., Lovely et al., 1991; Francis et al., 1994; Tucker et al., 1996). If the oxidation of labile organic matter in sediments is the prime mechanism dictating the sedimentary reducing conditions, then we might instead expect a universal relationship between the organic carbon oxidation rate and the authigenic $U$ accumulation rate. However, the 
relationship between organic carbon oxidation rate and authigenic $U$ accumulation is not universal (Figure 6B). There appear to be two trends with organic carbon oxidation rate predicting higher and lower authigenic $U$ accumulation rates. The trend predicting lower authigenic $U$ accumulation rates include results from California (Santa Monica and San Pedro; McManus et al., 2005, 2006), the Laurentian Trough, several MAB sites (EN4331 and OC426) and the two shallow bays (Hingham and Buzzards) (Figure 6B). It might be possible that authigenic $\mathrm{U}$ accumulation rates could be used as a rough proxy for past changes in organic carbon oxidation rates, if an independent constraint on bottom water oxygen concentration could be supplied. However, the lack of a global relationship further emphasizes the presence of additional mechanistic control(s) on authigenic $\mathrm{U}$ accumulation in sediments that could complicate the role of $\mathrm{U}$ as a paleo proxy for organic carbon oxidation.

The organic carbon rain rate is the sum of the organic carbon burial and oxidation rates. With additional locations from the MAB (Zheng et al., 2002a), a divergent relationship is also apparent for locations that underlie high $\left[\mathrm{O}_{2}\right]_{\mathrm{bw}}$ (Figure 6C). If PNU is not preserved at $\left[\mathrm{O}_{2}\right]_{\mathrm{bw}}>25 \mu \mathrm{M}$ (Zheng et al., 2002b), then it is likely that $\mathrm{U}$ accumulated in sediments is effectively decoupled from the organic carbon rain rate at locations with high bottom water oxygen. Remobilization of $U$ from sediments underlying oxygenated bottom waters may be enhanced due to bioturbation and/or irrigation exposing sediments containing authigenic $\mathrm{U}$ to oxygen-containing seawater (Zheng et al., 2002a; Morford et al., submitted). If high bottom water oxygen promotes irrigation and/or bioturbation that extends centimeters (or tens of centimeters) into sediments, then the accumulation of $U$ would not be expected to mimic $U$ accumulation in sediments underlying low $\left[\mathrm{O}_{2}\right]_{\mathrm{bw}}$.

The oxygen penetration depth will be a function of both the $\left[\mathrm{O}_{2}\right]_{\mathrm{bw}}$ and the carbon flux to sediments. As pointed out by McManus et al. (2005), there exists strong curvature in the relationship between authigenic $U$ accumulation and oxygen penetration depth (Figure 7). At oxygen penetration depths less than one centimeter, the authigenic accumulation of $U$ can vary by over a factor of forty. However, oxygen penetration 
depths greater than one centimeter suggest a consistent decrease in authigenic $U$ accumulation.

\section{CONCLUSIONS}

This work focused on three locations on the middle Atlantic Bight (MAB): a northern location on the continental shelf off Massachusetts (OC426, $75 \mathrm{~m}$ water depth), and two southern locations off North Carolina (EN433-1, 647 m water depth and EN4332, $2648 \mathrm{~m}$ water depth). Even though the sediments at all three locations underlie bottom water with high oxygen concentrations $(250-270 \mu \mathrm{M})$, the sediments become reducing below the sediment-water interface due to the relatively high organic carbon oxidation

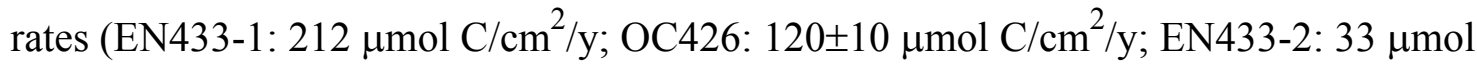
$\mathrm{C} / \mathrm{cm}^{2} / \mathrm{y}$ ). Pore water oxygen goes to zero by $1.4-1.5 \mathrm{~cm}$ at EN433-1 and OC426 and slightly deeper oxygen penetration depths were measured at EN433-2 ( 4 cm).

All of the pore water profiles show removal of $U$ from pore waters. Calculated pore water fluxes are greatest at EN433-1 $\left(0.66 \mathrm{nmol} / \mathrm{cm}^{2} / \mathrm{y}\right)$ and less at EN433-2 and OC426 (0.24 and $0.13 \mathrm{nmol} / \mathrm{cm}^{2} / \mathrm{y}$, respectively). The pore water profile from OC426 was more scattered than the other profiles, so the pore water flux is not as well constrained at this location. Solid phase profiles show authigenic $U$ enrichment in sediments from all three locations. The average authigenic concentrations are greater at EN433-1 and OC426 (5.8 $\pm 0.7 \mathrm{nmol} / \mathrm{g}$ and $5.4 \pm 0.2 \mathrm{nmol} / \mathrm{g}$, respectively) relative to EN433-2 (4.1 $\pm 0.8 \mathrm{nmol} / \mathrm{g})$ which is consistent with their relative ordering of 'reduction intensity', EN433-1 > OC426 > EN433-2. The average authigenic U accumulation rate for sediments from the $\operatorname{MAB}\left(\sim 0.2 \mathrm{nmol} / \mathrm{cm}^{2} / \mathrm{y}\right)$ is similar to the average rate of $\mathrm{U}$ accumulation measured along the California margin (McManus et al., 2005) and suggests a relatively consistent $U$ accumulation rate along continental margins. Measured $U$ accumulation rates are either equivalent to (OC426) or less than (EN433-1, EN433-2) calculated pore water fluxes. Pore water profiles suggest $U$ fluxes into sediments that are 1.4-1.7 times greater than authigenic accumulation rates for EN433-1 and EN433-2. These differences are consistent with oxidation and loss of $U$ from the solid phase via 
irrigation and/or bioturbation. The accumulation of $U$ at these locations emphasizes the importance of continental margin sediments underlying high bottom water oxygen as sinks for $U$. However the extent of its importance to the global mass balance of $U$ may be tempered by oxidative loss of previously accumulated solid phase $U$.

Previous literature compilations that include data exclusively from locations where $\left[\mathrm{O}_{2}\right]_{\mathrm{bw}}<150 \mu \mathrm{M}$ suggest compelling correlations between authigenic $\mathrm{U}$ accumulation and organic carbon flux to sediments and organic carbon burial rate. When this compilation is extended to include locations where $\left[\mathrm{O}_{2}\right]_{\mathrm{bw}}>150 \mu \mathrm{M}$, these relationships are not consistent among low and high $\left[\mathrm{O}_{2}\right]_{\mathrm{bw}}$ sites. Sediments that underlie waters with high $\left[\mathrm{O}_{2}\right]_{\mathrm{bw}}$ have lower authigenic $\mathrm{U}$ accumulation rates than would be predicted from relationships developed from results that include $\left[\mathrm{O}_{2}\right]_{\mathrm{bw}}<150 \mu \mathrm{M}$. This may be due to increased bioturbation and/or irrigation in sediments underlying high $\left[\mathrm{O}_{2}\right]_{\text {bw }}$ which leads to preferential $\mathrm{U}$ loss from sediments to overlying waters.

\section{Acknowledgements}

The authors would like to thank the captains and crews of Oceanus (OC426) and Endeavor (EN433). JLM also thanks co-chief scientist, Dr. Dan McCorkle, on EN433 for an enjoyable and productive cruise to the MAB. Joanne Goudreau (WHOI) was indispensable during equipment preparation and sample analysis. JLM acknowledges the ICP-MS expertise provided by Joanne Goudreau and Scot Birdwhistle (WHOI Plasma Facility). Carol Strausser, Lisa Mertzman and Steve Sylvester provided valuable support and assistance at F\&M. Comments and suggestions from Dr. Roberta Hamme and Dr. Hilairy Hartnett improved this manuscript. This paper also benefitted from suggestions from the associate editor, Dr. T. Shaw, Dr. Y. Zheng and an anonymous reviewer. The authors appreciate the financial support from NSF (JLM, WRM: OCE-0220892; and OCE-0526389 to WRM), Research Corporation (JLM, CMC), Franklin \& Marshall College, and the Hackman Summer Research Program (CMC) at F\&M.

\section{References}


Aller R. C. (1990) Bioturbation and manganese cycling in hemipelagic sediments. Phil. Trans. Roy. Soc. London A 331, 51-68.

Aller R. C. (1994) The sedimentary Mn cycle in Long Island Sound: Its role as intermediate oxidant and the influence of bioturbation, $\mathrm{O}_{2}$, and $\mathrm{C}_{\text {org }}$ flux on diagenetic reaction balances. Journal of Marine Research 52, 259-295.

Alperin M. J., Martens C. S., Albert D. B., Suayah I. B., Benninger L. K., Blair N. E. and Jahnke R. A. (1999) Benthic fluxes and porewater concentration profiles of dissolved organic carbon in sediments from the North Carolina continental slope. Geochim. Cosmochim. Acta, 63(3/4), 427-448.

Alperin M. J., Suayah I. B., Benninger L. K. and Martens C. S. (2002) Modern organic carbon burial fluxes, recent sedimentation rates, and particle mixing rates from the upper continental slope near Cape Hatteras, North Carolina (USA). Deep-Sea Res. II, 49, 4645-4665.

Anderson R. F. (1982) Concentration, vertical flux, and remineralization of particulate uranium in seawater. Geochim. Cosmochim. Acta 46, 1293-1299.

Andrews D. and Bennett A. (1981) Measurements of diffusivity near the sediment-water interface with a fine-scale resistivity probe. Geochim. Cosmochim. Acta 45, 21692175.

Anderson R. F., Bopp R. F., Buesseler K. O. and Biscaye P. E. (1988) Mixing of particles and organic constituents in sediments from the continental shelf and slope off Cape Cod: SEEP-I results. Continental Shelf Research, 8(5-7), 925-946.

Anderson R. F., LeHuray A. P., Fleisher M. Q. and Murray J. W. (1989) Uranium deposition in Saanich Inlet sediments, Vancouver Island. Geochim. Cosmochim. Acta 53, 2205-2213.

Anderson R. F., Rowe G. T., Kemp P. F., Trumbore S. and Biscaye P. E. (1994) Carbon budget for the mid-slope depocenter of the Middle Atlantic Bight. Deep Sea Res. II, 41(2-3), 669-703.

Anderson R. F., Kumar N., Mortlock R. A., Froelich P. N., Kubik P., Dittrich-Hannen B. and Suter M. (1998). Late-Quaternary changes in productivity of the Southern Ocean. Journal of Marine Systems 17, 497-514.

Bacon M. P., Belastock R. A. and Bothner M. H. (1994) 210Pb balance and implications for particle transport on the continental shelf, U.S. Middle Atlantic Bight. Deep Sea Res. II, 41(2/3), 511-535.

Barnes C. E. and Cochran J. K. (1990) Uranium removal in oceanic sediments and the oceanic U balance. Earth Planet. Sci. Lett. 97, 94-101.

Barnes C. E. and Cochran J. K. (1993) Uranium geochemistry in estuarine sediments: Controls on removal and release processes. Geochim. Cosmochim. Acta 57, 555-569.

Biscaye P. E. and Anderson R. F. (1994) Fluxes of particulate matter on the slope of the southern Middle Atlantic Bight: SEEP-II. Deep-Sea Res. II, 41(2/3), 459-509.

Biscaye P. E., Anderson R. F. and Deck B. L. (1988) Fluxes of particles and constituents to the eastern United States continental slope and rise: SEEP-I. Continental Shelf Res., 8(5-7), 855-904.

Bothner M. H., Spiker E. C., Johnson P. P., Rendigs R. R. and Aruscavage P. J. (1981) Geochemical evidence for modern sediment accumulation on the continental shelf off southern New England. J. Sedimentary Petrology, 51(1), 281-292. 
Boudreau B. P. (1997) Diagenetic Models and Their Implementation. Springer-Verlag, Berlin, p. 414.

Canfield D. E., Thamdrup B. and Hansen J. W. (1993) The anaerobic degradation of organic matter in Danish coastal sediments: Iron reduction, manganese reduction, and sulfate reduction. Geochim. Cosmochim. Acta 57, 3867-3883.

Chase Z., Anderson R. F. and Fleisher M. Q. (2001) Evidence from authigenic uranium for increased productivity of the glacial Subantarctic Ocean. Paleoceanography 2000PA000542.

Cochran J. K., Carey A. E., Sholkovitz E. R. and Surprenant L. D. (1986) The geochemistry of uranium and thorium in coastal marine sediments and sediment pore water. Geochim. Cosmochim. Acta 50, 663-680.

Crusius J., Calvert S., Pedersen T. and Sage D. (1996) Rhenium and molybdenum enrichments in sediments as indicators of oxic, suboxic and sulfidic conditions of deposition. Earth Planet. Sci. Lett. 145, 65-78.

Duff M. C., Coughlin J. U. and Hunter D. B. (2002) Uranium co-precipitation with iron oxide minerals. Geochim. Cosmochim. Acta 66, 3533-3547.

Farrenkopf A. M., Luther G. W., Truesdale V. W. and van der Weijden C. H. (1997) Subsurface iodide maxima: evidence for biologically catalyzed redox cycling in Arabian Sea OMZ during the SW intermonsoon. Deep-Sea Res. II, 44(6-7), 13911409.

Francis A. J., Dodge C. J., Lu F., Halada G. P. and Clayton C. R. (1994) XPS and XANES studies of uranium reduction by Clostridium sp. Environ. Sci. Technol. 28, 636-639.

François R. (1988) A study on the regulation of the concentrations of some trace metals $(\mathrm{Rb}, \mathrm{Sr}, \mathrm{Zn}, \mathrm{Pb}, \mathrm{Cu}, \mathrm{V}, \mathrm{Cr}, \mathrm{Ni}, \mathrm{Mn}$ and $\mathrm{Mo}$ ) in Saanich Inlet sediments, British Columbia. Mar. Geol. 83, 285-308.

Froelich P. N., Klinkhammer G. P., Bender M. L., Luedtke N. A., Heath G. R., Cullen D., Dauphin P., Hammond D., Hartman B. and Maynard V. (1979) Early oxidation of organic matter in pelagic sediments of the eastern equatorial Atlantic: suboxic diagenesis. Geochim. Cosmochim. Acta, 43, 1075-1090.

Gilbert D., Sundby B., Gobeil C., Mucci A. and Tremblay G.-H. (2005) A seventy-twoyear record of diminishing deep-water oxygen in the St. Lawrence estuary: The northwest Atlantic connection. Limnol. Oceanogr. 50(5), 1654-1666.

Glibert P. L. and Loder T. C. (1977) Automated analysis of nutrients in seawater: A manual of techniques. Technical Report, Woods Hole Oceanographic Institution, Woods Hole, MA.

Hartnett H. E. and Devol A. H. (2003) Role of a strong oxygen-deficient zone in the preservation and degradation of organic matter: A carbon budget for the continental margins of northwest Mexico and Washington State. Geochim. Cosmochim. Acta, 67(2), 247-264.

Hedges J. I., Hu F. S., Devol A. H., Hartnett H. E., Tsamakis E. and Keil R. G. (1999) Sedimentary organic matter preservation: A test for selective degradation under oxic conditions. Am. J. Sci. 299, 529-555.

Hsi C.-K. D. and Langmuir D. (1985) Adsorption of uranyl onto ferric oxyhydroxides: Application of the surface complexation site-binding model. Geochim. Cosmochim. Acta 49, 1931-1941. 
Jahnke R. A. and Jahnke D. B. (2000) Rates of C, N, P and Si recycling and denitrification at the US Mid-Atlantic continental slope depocenter. Deep-Sea Res. I, 47, 1405-1428.

Kalnejais L. H. (2005) Mechanisms of metal release from contaminated coastal sediments. Ph.D. thesis, Massachusetts Institute of Technology/Woods Hole Oceanographic Institution.

Klinkhammer G. P. and Palmer M. R. (1991) Uranium in the oceans: Where it goes and why. Geochim. Cosmochim. Acta 55, 1799-1806.

Kolodny Y. and Kaplan I. R. (1973) Deposition of uranium in the sediment and interstitial water of an anoxic fjord. In Proceedings of the Symposium on Hydrogeochemistry and Biogeochemistry, vol 1 (ed. E. Ingerson), pp. 418-442.

Ku, T. L., Knauss K. G., and Mathieu G. G. (1977) Uranium in the open ocean: concentration and isotopic composition. Deep-Sea Res. 24, 1005-1017.

Li Y. and Gregory S. (1974) Diffusion of ions in sea water and in deep-sea sediments. Geochim. Cosmochim. Acta 38, 703-714.

Lovley D. R., Phillips E. J. P., Gorby Y. A. and Landa E. R. (1991) Microbial reduction of uranium. Nature 350, 413-416.

Lyle M., Zahn R., Prahl F., Dymond J., Collier R., Pisias N. and Suess E. (1992) Paleoproductivity and carbon burial across the California current: the multitracers transect, 42oN. Paleoceanography, 7(3), 251-272.

Manheim F. T., Dwight L. and Belastock R. A. (1974) Porosity, density, grain density, and related physical properties of sediments from the Red Sea drill cores. In Initial Reports of the Deep Sea Drilling Project XXIII. v. 42, part 2 (eds. R. B. Whitmarsh, D. A. Ross) pp 887-907.

Martin W. R. and Sayles F. L. (2004) Organic matter cycling in sediments of the continental margin in the northwest Atlantic Ocean. Deep-Sea Res. I, 51, 457-489.

Martin W. R., Bender M., Leinen M., Orchardo J. (1991) Benthic organic carbon degradation and biogenic silica dissolution in the central equatorial Pacific. DeepSea Res. 38, 1481-1516.

McDuff R. E. and Ellis R. A. (1979) Determining diffusion coefficients in marine sediments: a laboratory study of the validity of resistivity techniques. American Journal of Science 279, 666-675.

McKee B. A., DeMaster D. J. and Nittrouer C. A. (1987) Uranium geochemistry on the Amazon shelf: Evidence for uranium release from bottom sediments. Geochim. Cosmochim. Acta 51, 2779-2786.

McManus J., Berelson W. M., Klinkhammer G. P., Hammond D. E. and Holm C. (2005) Authigenic uranium: relationship to oxygen penetration depth and organic carbon rain. Geochim. Cosmochim. Acta 69(1), 95-108.

McManus J., Berelson W. M., Severmann S., Poulson R. L., Hammond D. E., Klinkhammer G. P. and Holm C. (2006) Molybdenum and uranium geochemistry in continental margin sediments: Paleoproxy potential. Geochim. Cosmochim. Acta doi:10.1016/j.gca.2006.06.1564.

McNichol A. P., Lee C., and Druffel E. R. M. (1988) Carbon cycling in coastal sediments: 1. A quantitative estimate of the remineralization of organic carbon in the sediments of Buzzards Bay, MA. Geochim. Cosmochim. Acta 52, 1531-1543. 
Morford J. L and Emerson S. (1999) The geochemistry of redox sensitive trace metals in sediments. Geochim. Cosmochim. Acta 63, 1735-1750.

Morford J. L., Martin W. R., Kalnejais L. H., Francois R., Bothner M. and Karle I.-M. (2007) Insights on geochemical cycling of U, Re and Mo from seasonal sampling in Boston Harbor, Massachusetts, USA. Geochim. Cosmochim. Acta, 71, 895-917.

Morford J. L., Martin W. R., Francois R. and Carney C. M. (2008) A model for uranium, rhenium, and molybdenum diagenesis in marine sediments based on results from coastal locations. Submitted to Geochim. Cosmochim. Acta.

Murray R. W. and Leinen M. (1993) Chemical transport to the seafloor of the Equatorial Pacific Ocean across a latitudinal transect at $135^{\circ} \mathrm{W}$ : Tracking sedimentary major, trace and rare earth element fluxes at the Equator and the Intertropical Convergence Zone. Geochim. Cosmochim. Acta 57(17), 4141-4163.

Reimers C. E., Jahnke R. A. and McCorkle D. C. (1992) Carbon fluxes and burial rates over the continental slope and rise off Central California with implications for the global carbon cycle. Global Biogeochemical Cycles, 6(2), 199-224.

Rowe G. T., Theroux R., Phoel W., Quinby H., Wilke R., Koschoreck D., Whitledge T. E., Falkowski P. G. and Fray C. (1988) Benthic carbon budgets for the continental shelf south of New England. Cont. Shelf Res., 8(5-7), 511-527.

Sani R. K., Peyton B. M., Amonette J. E. and Geesey G. G. (2004) Reduction of uranium(VI) under sulfate-reducing conditions in the presence of $\mathrm{Fe}(\mathrm{III})$ (hydro)oxides. Geochim. Cosmochim. Acta 68(12), 2639-2648.

Santschi P. H., Li Y.-H., Bell J. J., Trier R. M. and Kawtaluk K. (1980) Pu in coastal marine environments. Earth Planet. Sci. Lett., 51, 248-265.

Sayles F. L., Martin W. R., Chase Z. and Anderson R. F. (2001) Benthic remineralization and burial of biogenic $\mathrm{SiO}_{2}, \mathrm{CaCO}_{3}$, organic carbon, and detrital material in the Southern Ocean along a transect at $170^{\circ}$ West. Deep-Sea Research II 48, 4323-4383.

Senko J. M., Istok J. D., Suflita J. M. and Krumholz L. R. (2002) In-situ evidence for uranium immobilization and remobilization. Environ. Sci. Technol. 36, 1491-1496.

Shaw T. J., Sholkovitz E. R. and Klinkhammer G. (1994) Redox dynamics in the Chesapeake Bay: the effect on sediment/water uranium exchange. Geochim. Cosmochim. Acta 58(14), 2985-2995.

Sherman D. M., Peacock C. L. and Hubbard C. G. (2008) Surface complexation of U(VI) on goethite $(\alpha-\mathrm{FeOOH})$. Geochim. Cosmochim. Acta 72, 298-310.

Silverberg N., Bakker J., Edenborn H. M. and Sundby B. (1987) Oxygen profiles and organic carbon fluxes in Laurentian Trough sediments. Netherlands J. Sea Res., 21(2), 95-105.

Silverberg N., Sundby B., Mucci A., Zhong S., Arakaki T., Hall P., Landen A., Tengberg A. (2000) Remineralization of organic carbon in eastern Canadian continental margin sediments. Deep-Sea Res. II, 47, 699-731.

Sirocko F., Sarntheln M., Erlenkeuser H., Lange H., Arnold M. and Duplessy J. C. (1993) Century-scale events in monsoonal climate over the past 24,000 years. Nature, 364, 322-324.

Smith J. N. and Schafer C. T. (1999) Sedimentation, bioturbation, and Hg uptake in the sediments of the estuary and Gulf of St. Lawrence. Limnol. Oceanogr., 44(1), 207219. 
Stump C. and Emerson S. (2001) Cruise Report of T. G. Thompson Cruise 131, University of Washington, Seattle, WA.

Sundby B., Martinez P. and Gobeil C. (2004) Comparative geochemistry of cadmium, rhenium, uranium, and molybdenum in continental margin sediments. Geochim. Cosmochim. Acta, 68(11), 2485-2493.

Talley L.D. (2007) Hydrographic Atlas of the World Ocean Circulation Experiment (WOCE). Volume 2: Pacific Ocean (eds. M. Sparrow, P. Chapman and J. Gould), International WOCE Project Office, Southampton, U.K.

Taylor S. R. and McLennan S. M. (1985) The Continental Crust: its Composition and Evolution. Blackwell Scientific Publications.

Thomas C. J., Blair N. E., Alperin M. J., DeMaster D. J., Jahnke R. A., Martens C. S. and Mayer L. (2002) Organic carbon deposition on the North Carolina continental slope off Cape Hatteras (USA). Deep-Sea Res. II, 49, 4687-4709.

Tucker M. D., Barton L. L. and Thomson B. M. (1996) Kinetic coefficients for simultaneous reduction of sulfate and uranium by Desulfovibrio desulfuricans. Appl. Microbiol. Biotechnol. 46, 74-77.

Turekian K. K. and Wedepohl K. H. (1961) Distribution of the elements in some major units of the earth's crust. Geol. Soc. Amer. Bull. 72, 175-192.

Zheng Y., Anderson R. F., van Geen A. and Kuwabara J. (2000) Authigenic molybdenum formation in marine sediments: A link to pore water sulfide in the Santa Barbara Basin. Geochim. Cosmochim. Acta, 64(24), 4165-4178.

Zheng Y., Anderson R. F., van Geen A. and Fleisher M. Q. (2002a) Remobilization of authigenic uranium in marine sediments by bioturbation. Geochim. Cosmochim. Acta, 66(10), 1759-1772.

Zheng Y., Anderson R. F., van Geen A. and Fleisher M. Q. (2002b) Preservation of particulate non-lithogenic uranium in marine sediments. Geochim. Cosmochim. Acta, 66(17), 3085-3092. 


\section{Figure captions}

Figure 1. Middle Atlantic Bight stations from cruise OC426 and EN433 (stations 1 and 2). Site OC426 is the same site as station 4722 (Bothner et al., 1981) and near station 1 of the SEEP-I transect (Biscaye et al., 1988). Sites EN433-1 and EN433-2 along the more southern portion of the MAB are nearby station locations for sediment traps from SYNOP (Zheng et al., 2002a and references therein) and SEEP-II (Biscaye and Anderson, 1994).

Figure 2. Bottom water and pore water results for oxygen, nitrate+nitrite, ammonium, $\mathrm{Fe}^{2+}, \mathrm{Mn}^{2+}$ and U from (A) OC426, (B) EN433-1, and (C) EN433-2. Horizontal lines denote the sediment-water interface. Filled symbols are for the whole-core squeezer samples, open symbols are for pore water samples from sliced/centrifuged sediments, and stars denote the bottom water concentrations. The bold lines denote the depth ranges over which the model profiles were fit to determine gradients for calculating fluxes.

Figure 3. Solid phase profiles of metal/aluminum molar ratios and organic carbon from EN433-1, EN433-2, and OC426. The dashed line denotes the detrital U/Al estimate, based on the average of the ratios for deep-sea clay (Turekian and Wedepohl, 1961) and upper continental crust (Taylor and McLennan, 1985). Note that organic carbon concentrations were not determined for sediments from OC426.

Figure 4. Porosity profiles for sediments from (A) EN433-1, EN433-2, and (B) OC426. A formation factor profile (C) is also presented for sediments from OC426. The slope $(1.95)$ of the $\log (1 / F)$ versus $\log (\phi)$ in plot (D) defines $v$ in the Winsauer relationship, $\mathrm{F}=\mathrm{c} \phi^{-v}$.

Figure 5. Solid phase results for (A) EN433-1 and (B) EN433-2 for excess ${ }^{210} \mathrm{~Pb}$ and ${ }^{234} \mathrm{Th}$.

Figure 6. The authigenic $U$ accumulation rates are plotted against (A) the organic carbon burial rates, $(\mathrm{B})$ the organic carbon oxidation rates, and $(\mathrm{C})$ the organic carbon rain rates. The data are fully described in Table 8. Data from locations with low bottom water oxygen $\left(\left[\mathrm{O}_{2}\right]_{\mathrm{bw}}<150 \mu \mathrm{M}\right)$ are plotted with open symbols. Locations 
with $\left[\mathrm{O}_{2}\right]_{\mathrm{bw}}>150 \mu \mathrm{M}$ are plotted with closed symbols and include Hingham and Buzzards bays, the Laurentian Trough, and all of the MAB locations (Zheng et al., 2002b; this work). (Note that station 1 from the Laurentian Trough has a range in bottom water oxygen that is less than $150 \mu \mathrm{M}$.) Ranges are included when available.

Figure 7. The authigenic $U$ accumulation rate plotted against the oxygen penetration depths for locations described in Table 8. 
Table 1. Comparison of sites from the southern (EN433-1 and EN433-2) and northern (OC426) areas of the middle Atlantic Bight (MAB).

\begin{tabular}{|c|c|c|c|}
\hline & EN433-1 & EN433-2 & OC426 \\
\hline Location & $\begin{array}{l}35^{\circ} 50.927^{\prime} \mathrm{N}, \\
74^{\circ} 49.462^{\prime} \mathrm{W}\end{array}$ & $\begin{array}{l}36^{\circ} 09.184^{\prime} \mathrm{N}, \\
74^{\circ} 03.343^{\prime} \mathrm{W}\end{array}$ & $\begin{array}{l}40^{\circ} 27.6^{\prime} \mathrm{N}, \\
70^{\circ} 32.7^{\prime} \mathrm{W}\end{array}$ \\
\hline Water depth (m) & 647 & 2648 & 75 \\
\hline Bottom water $\left[\mathrm{O}_{2}\right](\mu \mathrm{M})^{a}$ & 247 & 270 & 271 \\
\hline $\mathrm{O}_{2}$ penetration $(\mathrm{cm})^{a}$ & 1.4 & 4 & 1.5 \\
\hline Mass accumulation rate $\left(\mathrm{mg} / \mathrm{cm}^{2} / \mathrm{y}\right)$ & $81^{b}$ & $30 \pm 10^{c}$ & $24 \pm 7^{d}$ \\
\hline Solid phase organic carbon content (\%) & $2.7 \pm 0.2^{\mathrm{e}}$ & $0.89 \pm 0.09^{\mathrm{e}}$ & $1.5-1.7^{\mathrm{d}, \mathrm{f}}$ \\
\hline $\begin{array}{l}\text { Organic matter oxidation rate } \\
\left(\mu \mathrm{mol} \mathrm{C} / \mathrm{cm}^{2} / \mathrm{y}\right)^{\mathrm{a}}\end{array}$ & 212 & 33 & $120 \pm 10$ \\
\hline
\end{tabular}

a. This work.

b. The accumulation rate for EN433-1 was determined from modeling excess ${ }^{210} \mathrm{~Pb}$ and fallout $\mathrm{Pu}$ (Alperin et al., 2002).

c. The accumulation rate used for EN433-2 is from ${ }^{14} \mathrm{C}$ analysis from gravity cores from adjacent locations that range from 22-45 g/cm²/kyr (Anderson et al., 1994).

d. The accumulation rate used for OC426 is from ${ }^{14} \mathrm{C}$ analysis of two sediment cores recovered from nearby locations at similar water depths (Bothner et al., 1981).

e. The solid phase organic carbon concentrations are the average concentrations from deeper than $6 \mathrm{~cm}$ below the sediment-water interface (this work).

f. Anderson et al. (1988). 
Table 2. Pore water metal concentrations from EN433-1, EN433-2 and OC426. The depth is in cm, U concentration is in $\mathrm{nmol} / \mathrm{kg}$, and the $\mathrm{Mn}$ and Fe concentrations are in $\mu \mathrm{M}$. Note: $<\mathrm{DL}$ means that the measured concentration was less than the detection limit, which was $1 \mu \mathrm{M}$ and $2 \mu \mathrm{M}$ for $\mathrm{Mn}$ and Fe, respectively; '-' denotes that the species was not measured.

\begin{tabular}{|r|c|c|c|c|c|c|c|c|c|c|c|}
\hline $\begin{array}{l}\text { EN433-1 } \\
\text { Depth }\end{array}$ & [U] & [Mn] & [Fe] & $\begin{array}{l}\text { EN433-2 } \\
\text { Depth }\end{array}$ & [U] & [Mn] & [Fe] & $\begin{array}{l}\text { OC426 } \\
\text { Depth }\end{array}$ & [U] & [Mn] & [Fe] \\
\hline bw $^{\mathrm{a}}$ & 13.1 & - & - & bw $^{\mathrm{a}}$ & 13.1 & - & - & ovw $^{\mathrm{b}}$ & 12.4 & - & - \\
\hline $\mathrm{ovw}^{\mathrm{b}}$ & 13.3 & - & - & $\mathrm{ovw}^{\mathrm{b}}$ & 13.0 & - & - & 0.18 & 13.0 & $<\mathrm{DL}$ & 3.88 \\
\hline 0.18 & 12.2 & 14.1 & $<\mathrm{DL}$ & 0.18 & 11.8 & - & - & 0.53 & 12.1 & 1.19 & $<\mathrm{DL}$ \\
\hline 0.53 & 10.3 & - & - & 0.53 & 12.0 & $<\mathrm{DL}$ & $<\mathrm{DL}$ & 0.88 & 11.8 & 11.5 & $<\mathrm{DL}$ \\
\hline 0.88 & 9.65 & 24.2 & 19.8 & 0.88 & 11.2 & - & - & 1.23 & 12.4 & - & - \\
\hline 1.23 & 8.87 & - & - & 1.23 & 10.9 & $<\mathrm{DL}$ & $<\mathrm{DL}$ & 1.71 & 11.7 & 14.9 & 18.5 \\
\hline 1.71 & 7.29 & 19.6 & 61.0 & 1.71 & 10.7 & - & - & 2.33 & - & 12.7 & 49.5 \\
\hline 2.95 & 4.83 & 6.42 & 60.3 & 2.33 & - & $<\mathrm{DL}$ & $<\mathrm{DL}$ & 2.95 & 7.70 & - & - \\
\hline 4.18 & 3.21 & 4.57 & 40.9 & 2.95 & 9.96 & - & - & 3.57 & - & 8.99 & 72.0 \\
\hline 5.42 & 2.56 & 2.74 & 15.4 & 3.57 & - & $<\mathrm{DL}$ & $<\mathrm{DL}$ & 4.18 & 9.35 & - & - \\
\hline 6.65 & 3.02 & 1.76 & $<\mathrm{DL}$ & 4.18 & 9.21 & - & - & 4.80 & - & 3.46 & 16.3 \\
\hline 7.89 & 3.10 & $<\mathrm{DL}$ & $<\mathrm{DL}$ & 4.80 & - & 14.1 & 2.23 & 5.42 & 7.65 & - & - \\
\hline 9.31 & - & 1.34 & $<\mathrm{DL}$ & 5.42 & 8.12 & - & - & 6.04 & - & 1.82 & 20.5 \\
\hline 10.31 & 3.60 & - & - & 6.04 & - & 28.7 & $<\mathrm{DL}$ & 7.27 & - & 1.15 & 11.7 \\
\hline 11.31 & - & $<\mathrm{DL}$ & $<\mathrm{DL}$ & 6.65 & 8.07 & - & - & 8.51 & 6.98 & $<\mathrm{DL}$ & $<\mathrm{DL}$ \\
\hline 12.31 & 3.30 & - & - & 7.27 & - & 28.0 & 4.62 & 9.43 & - & $<\mathrm{DL}$ & $<\mathrm{DL}$ \\
\hline 13.81 & - & $<\mathrm{DL}$ & $<\mathrm{DL}$ & 7.89 & 7.85 & - & - & 10.67 & - & $<\mathrm{DL}$ & $<\mathrm{DL}$ \\
\hline 15.81 & 2.17 & - & - & 8.51 & - & 37.0 & 5.53 & 11.90 & 7.13 & $<\mathrm{DL}$ & $<\mathrm{DL}$ \\
\hline 17.81 & - & $<\mathrm{DL}$ & $<\mathrm{DL}$ & 9.31 & - & 33.8 & 6.11 & 13.14 & 5.88 & $<\mathrm{DL}$ & $<\mathrm{DL}$ \\
\hline 19.81 & 2.56 & - & - & 11.31 & - & 26.0 & 11.6 & & & & \\
\hline & & & & 12.31 & 3.97 & - & - & & & & \\
\hline & & & & 13.81 & - & 20.6 & 20.5 & & & & \\
\hline & & & & 15.81 & 2.93 & - & - & & & & \\
\hline & & & & 17.81 & - & 21.7 & 5.87 & & & & \\
\hline
\end{tabular}

a. The bottom water samples (bw) were obtained from CTD casts that were $\sim 95 \mathrm{~m}$ above the seafloor at EN433-1 and 750 m above the seafloor at EN433-2.

b. The overlying water samples (ovw) were obtained from immediately above the sediment-water interface prior to sectioning the core. 
Table 3. Certified (Al, Fe, Mn) and recommended (U) concentrations for the standard sediment, PACS-2, are compared with average metal concentrations, standard deviations and relative standard deviations $(\mathrm{n}=6)$. The $\mathrm{Al}, \mathrm{Fe}$ and Mn analyses ( $\mu \mathrm{mol} / \mathrm{g}_{\mathrm{sed}}$ ) were completed using ICPOES, and the $\mathrm{U}$ analyses (nmol/gsed) were determined using ICP-MS.

\begin{tabular}{|l|l|l|l|l|}
\hline & \multicolumn{1}{|c|}{ [Al] } & \multicolumn{1}{|c|}{ [Fe] } & \multicolumn{1}{|c|}{ [Mn] } & \multicolumn{1}{c|}{ [U] } \\
\hline $\begin{array}{l}\text { Ave } \pm \text { std dev } \\
\text { (\%RSD) }\end{array}$ & $2,330 \pm 20$ & $680 \pm 20$ & $7.9 \pm 0.2$ & $9.1 \pm 0.4^{\text {a }}$ \\
$(0.9 \%)$ & $(3 \%)$ & $(2 \%)$ & $(4 \%)$ \\
\hline Known conc. & $2,400 \pm 100$ & $730 \pm 10$ & $8.0 \pm 0.4$ & $13^{\mathrm{b}}$ \\
\hline
\end{tabular}

a. This concentration is consistent with previous measurements of U content in PACS-2, which have yielded $9.3 \pm 0.3 \mathrm{nmol} / \mathrm{g}_{\text {sed }}\left(\mathrm{n}=6\right.$; Morford et al., submitted) and $9.8 \pm 0.4 \mathrm{nmol} / \mathrm{g}_{\text {sed }}(\mathrm{n}=5$; Morford et al., 2007). The later average measurement was determined using a different total dissolution/ICP-MS method relative to the former measurement.

b. Recommended concentration. 
Table 4. Solid phase metal concentrations from EN433-1, EN433-2 and OC426. Note: '-’ denotes that the species was not measured.

\begin{tabular}{|c|c|c|c|c|c|}
\hline EN433-1 & Depth (cm) & [Al] $(\mu \mathrm{mol} / \mathrm{g})$ & {$[\mathrm{Fe}](\mu \mathrm{mol} / \mathrm{g})$} & {$[\mathrm{Mn}](\mu \mathrm{mol} / \mathrm{g})$} & [U] (nmol/g) \\
\hline & 0.18 & 1716 & 453.0 & 9.41 & 7.53 \\
\hline & 0.88 & 1794 & 474.5 & 6.55 & 7.76 \\
\hline & 0.88 & 1783 & 479.9 & 6.99 & 7.70 \\
\hline & 1.71 & 1887 & 481.7 & 6.26 & 8.24 \\
\hline & 1.71 & 1823 & 474.5 & 6.39 & - \\
\hline & 2.95 & 1885 & 462.8 & 5.95 & 8.89 \\
\hline & 4.18 & 1968 & 484.2 & 5.73 & 9.55 \\
\hline & 5.42 & 1918 & 476.0 & 5.88 & 10.44 \\
\hline & 7.27 & 1965 & 503.5 & 5.82 & 10.77 \\
\hline & 9.31 & 1941 & 486.4 & 5.93 & 11.50 \\
\hline & 11.31 & 1981 & 483.9 & 5.93 & 11.59 \\
\hline & 11.31 & 1902 & 457.8 & 6.02 & 11.71 \\
\hline & 13.81 & 1977 & 506.9 & 6.15 & 11.99 \\
\hline & 15.81 & 1951 & 500.5 & 6.25 & 11.33 \\
\hline & 19.81 & 2032 & 494.6 & 6.43 & 10.12 \\
\hline EN433-2 & Depth (cm) & [Al] $(\mu \mathrm{mol} / \mathrm{g})$ & {$[\mathrm{Fe}](\mu \mathrm{mol} / \mathrm{g})$} & {$[\mathrm{Mn}](\mu \mathrm{mol} / \mathrm{g})$} & [U] (nmol/g) \\
\hline & 0.18 & 1768 & 438.7 & 14.33 & 6.16 \\
\hline & 0.88 & 1822 & 444.1 & 13.94 & 6.10 \\
\hline & 1.71 & 1864 & 442.7 & 13.65 & 6.25 \\
\hline & 2.95 & 1816 & 465.6 & 18.89 & 6.39 \\
\hline & 2.95 & 1880 & 460.2 & 18.60 & - \\
\hline & 4.18 & 1805 & 453.0 & 12.27 & 6.49 \\
\hline & 5.42 & 1816 & 456.6 & 7.46 & 7.07 \\
\hline & 7.27 & 1890 & 440.6 & 6.08 & 9.83 \\
\hline & 7.27 & 1822 & 451.5 & 6.24 & 9.98 \\
\hline & 9.31 & 1877 & 434.6 & 6.06 & 9.98 \\
\hline & 11.31 & 1929 & 440.9 & 6.28 & 9.38 \\
\hline & 13.81 & 1877 & 474.3 & 5.82 & - \\
\hline & 13.81 & 1926 & 488.7 & 6.19 & 8.61 \\
\hline & 17.81 & 1898 & 460.1 & 6.27 & 8.69 \\
\hline & 19.81 & 1871 & 467.2 & 6.43 & 10.56 \\
\hline & 19.81 & 1827 & 438.7 & 6.12 & \\
\hline OC426 & Depth (cm) & [Al] $(\mu \mathrm{mol} / \mathrm{g})$ & {$[\mathrm{Fe}](\mu \mathrm{mol} / \mathrm{g})$} & {$[\mathrm{Mn}](\mu \mathrm{mol} / \mathrm{g})$} & [U] (nmol/g) \\
\hline & 0.18 & 1537 & 337.6 & 6.08 & 8.11 \\
\hline & 0.88 & 1531 & 331.8 & 5.53 & 8.04 \\
\hline & 1.71 & 1523 & 330.1 & 5.07 & 8.18 \\
\hline & 1.71 & 1523 & 338.4 & 5.22 & 8.15 \\
\hline & 2.95 & 1522 & 326.9 & 5.23 & 8.44 \\
\hline & 4.18 & 1382 & 290.1 & 4.73 & 8.32 \\
\hline & 5.42 & 1423 & 302.6 & 4.85 & 9.13 \\
\hline & 7.27 & 1505 & 333.1 & 5.23 & 10.44 \\
\hline & 9.12 & 1449 & 331.3 & 4.64 & 9.75 \\
\hline & 9.12 & 1497 & 331.3 & 5.42 & 9.81 \\
\hline & 10.98 & 1497 & 334.8 & 5.24 & 9.32 \\
\hline & 12.21 & 1527 & 340.2 & 5.26 & 9.67 \\
\hline & 12.83 & 1508 & 334.8 & 4.82 & 9.85 \\
\hline & 13.45 & 1538 & 351.0 & 5.46 & 9.78 \\
\hline
\end{tabular}


Table 5. Organic carbon oxidation rates as determined from the reduction of oxygen, nitrate, sulfate (as determined from ammonium profiles), Mn, and Fe from the MAB sites EN433-1, EN433-2 and OC426. Negative fluxes indicate a flux out of sediments.

\begin{tabular}{|c|c|c|c|c|c|}
\hline Oxidant & Location & $\begin{array}{c}\text { Gradient } \\
\left(\mu \mathrm{mol} / \mathrm{cm}^{4}\right)^{a}\end{array}$ & $\begin{array}{l}\text { Oxidant Flux } \\
\left(\mu \mathrm{mol} / \mathrm{cm}^{2} / \mathrm{y}\right)\end{array}$ & $\begin{array}{l}C_{\text {org ox rate }} \text { ox }^{2} \\
\left(\mu \mathrm{mol} / \mathrm{cm}^{2} / \mathrm{y}\right)\end{array}$ & $\begin{array}{l}\text { Percent of total } \\
\mathrm{C}_{\text {org }} \text { ox rate (\%) }\end{array}$ \\
\hline \multirow{3}{*}{$\mathrm{O}_{2}{ }^{\mathrm{C}}$} & EN433-1 & -0.263 & 86.9 & 63 & 30 \\
\hline & EN433-2 & -0.124 & 34.6 & 25 & 75 \\
\hline & OC426 & -0.269 to $-0.368^{\mathrm{d}}$ & 80.0 to 109.2 & $60 \pm 10$ & 49 \\
\hline \multirow{3}{*}{$\mathrm{NO}_{3}^{-}$} & EN433-1 & -0.0496 & $12.7^{\mathrm{e}}$ & 14.2 & 6.7 \\
\hline & EN433-2 & -0.0070 & $2.03^{f}$ & 2.3 & 6.9 \\
\hline & OC426 & -0.0105 & $8.70^{\mathrm{g}}$ & 9.8 & 8.0 \\
\hline \multirow[t]{3}{*}{$\mathrm{NH}_{4}{ }^{+h}$} & EN433-1 & 0.0867 & -19.8 & 130.2 & 61 \\
\hline & EN433-2 & 0.0050 & -0.88 & 5.8 & 17 \\
\hline & OC426 & 0.0328 & -7.91 & 51.6 & 42 \\
\hline \multirow[t]{3}{*}{$\mathrm{Mn}^{2+}$} & EN433-1 & 0.0800 & -6.98 & 3.14 & 1.5 \\
\hline & EN433-2 & 0.0116 & -0.57 & 0.25 & $<1$ \\
\hline & OC426 & 0.0295 & -2.27 & 1.02 & $<1$ \\
\hline \multirow[t]{3}{*}{$\mathrm{Fe}^{2+}$} & EN433-1 & 0.0494 & -3.74 & 0.94 & $<1$ \\
\hline & EN433-2 & 0.0036 & -0.17 & 0.04 & $<1$ \\
\hline & OC426 & 0.0501 & -3.16 & 0.79 & $<1$ \\
\hline Sum & $\begin{array}{c}\text { EN433-1 } \\
\text { EN433-2 } \\
\text { OC426 }\end{array}$ & & & $\begin{array}{l}212 \\
33 \\
120 \pm 10\end{array}$ & \\
\hline
\end{tabular}

a. Lines on the pore water profiles show the depth ranges used to determine the gradients (Figure 2).

b. Stoichiometries to convert oxidant fluxes to organic carbon oxidation rates are from Reimers et al. (1992).

c. The benthic oxygen flux is the total flux across the sediment-water interface. To determine the aerobic organic carbon oxidation rates, we assumed that a portion of the benthic oxygen flux oxidizes reduced inorganic species in addition to oxidizing organic matter. The benthic $\mathrm{O}_{2}$ flux is decreased according to the $\mathrm{NH}_{4}^{+}, \mathrm{Mn}^{2+}$, $\mathrm{Fe}^{2+}$ production rates and their respective stoichiometries (Reimers et al., 1992; Hartnett and Devol, 2003). The consumption of oxygen via sulfide oxidation was not included; the correction would be trivial for EN4332 where $\mathrm{NH}_{4}{ }^{+}$production is small suggesting that sulfide production is minimal. The correction would be larger at OC426 yielding an aerobic carbon oxidation rate of $30 \pm 20 \mu \mathrm{mol} / \mathrm{cm}^{2} / \mathrm{y}$ and a total organic carbon oxidation rate in sediments of $80 \pm 10 \mu \mathrm{mol} / \mathrm{cm}^{2} / \mathrm{y}$. The amount of sulfide produced at EN433-1 (66 $\mu \mathrm{mol} / \mathrm{cm}^{2} / \mathrm{y}$ based on $\mathrm{NH}_{4}{ }^{+}$production rate) would require more oxygen than is available to effectively oxidize all of the sulfide produced. The decreasing $\mathrm{Fe}^{2+}$ pore water profiles at OC426 and EN433-1 suggest some precipitation of iron sulfide at depth, so oxidation of sulfide has been omitted from the benthic oxygen flux correction.

$\mathrm{d}$. The range in gradients at OC426 is due to modeling the data from $0-1 \mathrm{~cm}$ and $0-1.4 \mathrm{~cm}$.

e. We assume that the $\mathrm{NH}_{4}{ }^{+}$production rate is equivalent to its benthic flux so that $\mathrm{NH}_{4}{ }^{+}$oxidation in sediments is negligible and no additional $\mathrm{NO}_{3}{ }^{-}$is produced to augment denitrification (Hartnett and Devol, 2003).

f. The total $\mathrm{NO}_{3}{ }^{-}$flux includes $\mathrm{NO}_{3}{ }^{-}$produced during $\mathrm{NH}_{4}{ }^{+}$oxidation, which is assumed to occur completely within the sediments.

g. The benthic $\mathrm{NH}_{4}{ }^{+}$flux to overlying waters $\left(1.53 \mu \mathrm{mol} / \mathrm{cm}^{2} / \mathrm{y}\right)$ was subtracted from the $\mathrm{NH}_{4}{ }^{+}$production rate $\left(7.91 \mu \mathrm{mol} / \mathrm{cm}^{2} / \mathrm{y}\right)$ to determine the amount of $\mathrm{NO}_{3}{ }^{-}$generated in sediments due to $\mathrm{NH}_{4}{ }^{+}$oxidation (6.38 $\mu \mathrm{mol} / \mathrm{cm}^{2} / \mathrm{y}$ ). This was added to the $\mathrm{NO}_{3}{ }^{-}$flux to calculate the total amount of denitrification.

h. The $\mathrm{NH}_{4}{ }^{+}$production rates are determined from the steepest gradient in the profile, except at EN433-1 where an exponential fit to the data is applied from $0-1.7 \mathrm{~cm}$ to constrain the gradient across the sediment-water interface. The contribution of $\mathrm{NH}_{4}{ }^{+}$from Fe reduction has been subtracted to determine the organic carbon oxidation rate due to sulfate reduction (Reimers et al., 1992). 
Table 6. Pore water U model results for fittable parameters.

\begin{tabular}{|l|c|c|c|c|c|}
\hline Location & $\begin{array}{c}\mathbf{M}_{\mathbf{1}} \\
(\mathbf{n m o l} / \mathbf{k g})\end{array}$ & $\begin{array}{c}\mathbf{M}_{\mathbf{2}} \\
\left.\mathbf{( c m}^{-1}\right)\end{array}$ & $\begin{array}{c}\left([\mathbf{U}]_{\mathbf{b w}}\right)_{\mathbf{m o d e l}} \\
(\mathbf{n m o l} / \mathbf{k g})\end{array}$ & $\begin{array}{c}\left([\mathbf{U}]_{\mathbf{b w}}\right)_{\text {measured }} \\
(\mathbf{n m o l} / \mathbf{k g})\end{array}$ & $\begin{array}{c}\text { Flux }_{\mathbf{U}} \\
\left(\mathbf{n m o l} / \mathbf{c m}^{2} / \mathbf{y}\right)\end{array}$ \\
\hline EN433-1 & $2.3 \pm 0.4$ & $0.48 \pm 0.05$ & $13.1 \pm 0.3$ & $13.2 \pm 0.2$ & $0.66 \pm 0.08$ \\
\hline EN433-2 & $9.0 \pm 0.3$ & $0.6 \pm 0.1$ & $13.0 \pm 0.2$ & $13.07 \pm 0.05$ & $0.24 \pm 0.05^{\mathrm{a}}$ \\
\hline OC426 & $6.0 \pm 0.9$ & $0.23 \pm 0.09$ & $13.1 \pm 0.5$ & $12.6 \pm 0.3$ & $0.13 \pm 0.05$ \\
\hline
\end{tabular}

a. For comparison, linear fits were also used to model the pore water profile from EN433-2. A linear fit from 0-0.18 cm resulted in a Flux $x_{U}$ of $0.76 \mathrm{nmol} / \mathrm{cm}^{2} / \mathrm{y}$, whereas a linear fit from 0-1.71 cm resulted in a Flux $\mathrm{U}$ of $0.109 \mathrm{nmol} / \mathrm{cm}^{2} / \mathrm{y}$. The linear fits result in variable fluxes that depend on the modeled depth range. The large difference between the fluxes calculated with the linear models is due to the curvature inherent in the pore water profile, which is adequately captured by the exponential model (see exponential fit on Figure 2). 
Table 7. Authigenic $U$ concentrations and accumulation rates for locations with high bottom water oxygen concentrations based on solid phase results. Mass accumulation rates for the MAB sites are on Table 1.

\begin{tabular}{|l|c|c|}
\hline & $\begin{array}{c}\text { [U] }_{\text {Auth }}^{\text {b }} \\
\left(\mathbf{n m o l} / \mathbf{g}_{\text {sed }}\right)\end{array}$ & $\begin{array}{c}\mathbf{U}_{\text {Auth }} \text { accumulation rate }^{\mathbf{c}} \\
\left(\mathbf{n m o l} / \mathbf{c m}^{\mathbf{2}} / \mathbf{y}\right)\end{array}$ \\
\hline Hingham Bay $^{\mathbf{a}}$ & $5 \pm 2$ & $1.3 \pm 0.05$ \\
\hline Buzzards Bay $^{\mathbf{a}}$ & $4.2 \pm 0.1$ & $0.4 \pm 0.1$ \\
\hline S. MAB - EN433-1 & $5.8 \pm 0.7^{\mathrm{b}}$ & $0.47 \pm 0.05$ \\
\hline - EN433-2 & $4.1 \pm 0.8^{\mathrm{b}}$ & $0.14 \pm 0.04$ \\
\hline N. MAB - OC426 & $5.4 \pm 0.2^{\mathrm{b}}$ & $0.13 \pm 0.04$ \\
\hline
\end{tabular}

a. Data from Morford et al., 2007; Morford et al., submitted.

b. The authigenic $\mathrm{U}$ concentration $\left([\mathrm{U}]_{\text {Auth }}\right)$ is determined as: $[\mathrm{U}]_{\text {Auth }}=[\mathrm{U}]_{\mathrm{m}}-\left(\left(\frac{\mathrm{U}}{\mathrm{Al}}\right)_{\mathrm{d}} \mathrm{x}[\mathrm{Al}]_{\mathrm{m}}\right)$. The measured $\mathrm{U}$ and $\mathrm{Al}$ concentrations $\left([\mathrm{U}]_{\mathrm{m}},[\mathrm{Al}]_{\mathrm{m}}\right)$ are the calculated averages below $9 \mathrm{~cm}$ in each solid phase profile. The detrital U/Al ratio, $\left(\frac{\mathrm{U}}{\mathrm{Al}}\right)_{\mathrm{d}}$, is $2.8 \times 10^{-6} \mathrm{~mol} / \mathrm{mol}$, which is the average U/Al ratio calculated from deep-sea clay (Turekian and Wedepohl, 1961) and upper continental crust (Taylor and McLennan, 1985).

c. The authigenic $U$ accumulation rate is calculated as: $U_{\text {AuthAcc }}=[U]_{\text {Auth }} x($ MAR $)$. The mass accumulation rates (MAR) are from adjacent locations (Tables 1 and 8). 
Table 8. Compilation of results from the literature (see references below), Hingham and Buzzards bays

(Morford et al., 2007; Morford et al., submitted), and northern and southern locations from the MAB (this work).

\begin{tabular}{|c|c|c|c|c|c|c|c|c|c|}
\hline Site & \begin{tabular}{|l|}
$\begin{array}{l}\text { Depth } \\
(\mathrm{m})\end{array}$ \\
\end{tabular} & $\begin{array}{l}{\left[\begin{array}{l}{\left[\mathbf{O}_{2}\right]_{\mathbf{b w}}} \\
(\mu \mathrm{M})\end{array}\right.} \\
\end{array}$ & \begin{tabular}{|l|}
$\mathbf{O}_{2, p e n}$ \\
$(\mathrm{~cm})$
\end{tabular} & $\begin{array}{l}\text { MAR } \\
\left(\mathrm{mg} / \mathrm{cm}^{2} / \mathrm{y}\right)\end{array}$ & $\begin{array}{l}{\left[\mathbf{C}_{\text {org }}\right]} \\
(\%)\end{array}$ & $(\mathrm{mm}$ & $\begin{array}{c}\mathbf{C}_{\text {burial }} \\
\mathrm{ol} / \mathrm{m}^{2} / \mathrm{d} \text { ) }\end{array}$ & $\mathrm{C}_{\text {rain }}$ & $\begin{array}{l}\mathbf{U} \\
\left(\mathrm{nmol} / \mathrm{m}^{2} / \mathrm{d}\right)\end{array}$ \\
\hline \multicolumn{10}{|c|}{ Pacific margin off California and Mexico (McManus et al., 2005, 2006) } \\
\hline Santa Monica & 905 & $4-10$ & \begin{tabular}{|l|}
0.3 \\
\end{tabular} & 16 & $4 \pm 1$ & $1.9 \pm 0.2$ & $1.5 \pm 0.4$ & $3.4 \pm 0.6$ & $9 \pm 3$ \\
\hline San Pedro & 896 & $3-8$ & 0.2 & 29 & $3.9 \pm 0.9$ & $1.8 \pm 0.4$ & $2.6 \pm 0.6$ & $4 \pm 1$ & $11 \pm 2$ \\
\hline Catalina & 1300 & 19 & 0.6 & 14 & $4 \pm 1$ & $1.3 \pm 0.1$ & $1.2 \pm 0.3$ & $2.5 \pm 0.4$ & $9 \pm 2$ \\
\hline Tanner & 1514 & 27 & 0.4 & 12 & $6.4 \pm 0.6$ & $1.0 \pm 0.3$ & $1.8 \pm 0.2$ & $2.8 \pm 0.5$ & $11 \pm 2$ \\
\hline San Clemente & 2053 & 65 & 1.3 & 15 & $3.2 \pm 0.3$ & $1.0 \pm 0.1$ & 0.9 & 1.9 & $6 \pm 1$ \\
\hline Patton Escarp. & 3707 & 132 & 2.9 & 3 & $1.1 \pm 0.2$ & $0.4 \pm 0.1$ & 0.08 & 0.5 & 0.4 \\
\hline Mazatlan & 442 & 0.2 & & 9 & & 1.1 & $1.7 \pm 0.1$ & 2.8 & $11 \pm 4$ \\
\hline San Blass & 430 & 0 & & 21 & & $>1.3$ & $3.2 \pm 0.2$ & 4.5 & $21 \pm 9$ \\
\hline Soledad & 542 & 0 & & 50 & & $>1.8$ & $8.4 \pm 0.3$ & 10.2 & $51 \pm 8$ \\
\hline \multicolumn{10}{|c|}{ Basins and MAB locations (Zheng et al., 2002b) } \\
\hline San Clemente & 1585 & 57 & & 5.5 & & & & 1.8 & 2.3 \\
\hline Santa Barbara B. & $340-590$ & $3-23$ & & $65-242$ & & & & 6.4 & $17-35$ \\
\hline Framvaren & & 0 & 0 & 9 & & & & 5 & 14.5 \\
\hline Black Sea & $2094-2218$ & 0 & 0 & $9 \pm 5$ & & & & 2 & $10 \pm 5$ \\
\hline Cariaco B. & & 0 & 0 & 13 & & & & 2 & 9.0 \\
\hline MAB BC4 & 512 & 200 & & 26 & & & & 5.4 & 1.8 \\
\hline MAB BC5 & 1045 & 190 & & 26 & & & & 5.4 & 2.8 \\
\hline MAB BC9 & 1165 & 220 & & 41 & & & & 5.4 & 7.4 \\
\hline MAB BC6 & 2000 & 270 & & 26 & & & & 5.0 & 2.2 \\
\hline \multicolumn{10}{|c|}{ Saanich Inlet, Pacific margin off of California, Western Arabian Sea (Anderson et al., 1998) } \\
\hline Saanich Inlet $^{\mathrm{a}}$ & $200-240$ & 0 & \begin{tabular}{|l|l|}
0 & \\
\end{tabular} & $100 \pm 20$ & $2-5$ & & $5-11$ & $13 \pm 4$ & 40 \\
\hline $\begin{array}{l}\text { N. CA Margin- } \\
\text { Midway }\end{array}$ & 3111 & 110 & & 4.2 & $1.18 \pm 0.06$ & $0.3 \pm 0.1^{\mathrm{C}}$ & $0.11 \pm 0.01$ & $0.4 \pm 0.1$ & 0.62 \\
\hline $\begin{array}{l}\text { N. CA Margin- } \\
\text { Nearshore }\end{array}$ & 2712 & 100 & & 9.3 & $1.7 \pm 0.3$ & $0.6 \pm 0.2^{c}$ & $0.36 \pm 0.06$ & $1.0 \pm 0.2$ & 3.1 \\
\hline W. Arabian Sea ${ }^{\mathrm{d}}$ & 3212 & 130 & & 7 & $0.7 \pm 0.2$ & $0.7^{\mathrm{C}}$ & $0.11 \pm 0.03$ & 0.8 & 3.2 \\
\hline \multicolumn{10}{|c|}{ NE Pacific margin off Washington/Oregon (Morford et al., 2005; Stump and Emerson, 2001) ${ }^{e}$} \\
\hline Stn 2 & 434 & 40 & \begin{tabular}{|l|}
0.3 \\
\end{tabular} & 9 & \begin{tabular}{|l|}
1.2 \\
\end{tabular} & 0.8 & 0.3 & 1.1 & 0.58 \\
\hline Stn 4 & 1961 & 55 & 0.5 & 5 & 2.3 & 0.8 & 0.3 & 1.1 & 0.62 \\
\hline Stn 6 & 2807 & 81 & 1.5 & 0.6 & 1 & 0.4 & 0.01 & 0.36 & 0 \\
\hline Stn 8 & 3866 & 124 & 5 & 2 & 1 & 0.1 & 0.04 & 0.18 & 0 \\
\hline \multicolumn{10}{|c|}{ Laurentian Trough, eastern Canadian continental margin } \\
\hline $\operatorname{Stn} 1^{\mathrm{f}}$ & $190-250$ & $75-105$ & \begin{tabular}{|l|l|}
0.5 \\
\end{tabular} & $300-500$ & 1.6 & 1.9 & $10-20$ & $12-22$ & 21 \\
\hline $\operatorname{Stn} 2^{g}$ & & $150-250$ & 0.9 & $30-100$ & $1.5-1.9$ & 2 & $1-3$ & $3-5$ & 9.3 \\
\hline $\operatorname{Stn} 4^{\mathrm{g}}$ & $190-350$ & $180-200$ & 1 & 30 & 1.9 & 2 & 1 & 3 & 4.7 \\
\hline Hingham Bay ${ }^{\mathrm{h}}$ & 5 & $310 \pm 70$ & $0.4 \pm 0.3$ & $270 \pm 50$ & $3.2 \pm 0.2$ & 24 & $20 \pm 4$ & $44 \pm 4$ & $36 \pm 1$ \\
\hline Buzzards Bay ${ }^{j}$ & 15 & $265 \pm 35$ & $0.55 \pm 0.05$ & $100 \pm 30$ & 1.5 & $11 \pm 1$ & $4 \pm 1$ & $15 \pm 1$ & $12 \pm 4$ \\
\hline S.MAB EN433-1 ${ }^{\mathrm{k}}$ & 647 & 247 & 1.4 & 81 & $2.7 \pm 0.2$ & 5.8 & 5.5 & 11.3 & $13 \pm 1$ \\
\hline EN433-2 ${ }^{\mathrm{m}}$ & 2648 & 270 & 4 & $30 \pm 10$ & $0.89 \pm 0.09$ & 0.9 & $0.7 \pm 0.2$ & $1.6 \pm 0.2$ & $4 \pm 1$ \\
\hline N. MAB OC426 ${ }^{\mathrm{n}}$ & 75 & 271 & 1.5 & $24 \pm 7$ & $1.5-1.7$ & $3.3 \pm 0.3$ & $0.82-1.2$ & $4.3 \pm 0.4$ & $4 \pm 1$ \\
\hline
\end{tabular}

a. Data from Anderson et al. (1989; mass accumulation rate, organic carbon flux) and Kolodny and Kaplan (1973; stations 2, 4; authigenic U concentration, organic carbon concentration). 
b. Data from Lyle et al. (1992) except for the bottom water oxygen concentrations (transect P17; Talley, 2007) and the U accumulation rate (Anderson et al., 1998). The average annual organic carbon rain rate was determined from sediment traps deployed for 2.5 years, and the standard deviation reflects the variability measured from year 1 to year 2 .

c. The organic carbon oxidation rate is the calculated difference between the organic carbon rain rate and the organic carbon burial rate.

d. Data from Sirocko et al. (1993) except for the bottom water oxygen concentration (Farrenkopf et al., 1997) and the U accumulation rate (Anderson et al., 1998).

e. Mass accumulation rates (MAR) for the NE Pacific margin off Washington/Oregon states used the sedimentation rates and organic carbon concentrations from Hedges et al. (1999) from nearby locations.

f. Data from Silverberg et al. (1987) except for the depth and bottom water oxygen concentration (Gilbert et al., 2005), mass accumulation rate (Smith and Schafer, 1999) and the U accumulation rate (Sundby et al., 2004). Note that the sum of the organic carbon oxidation and burial rates results in the calculated organic carbon rain rate for station 1 from the Laurentian Trough (12-22 mmol/ $\left.\mathrm{m}^{2} / \mathrm{d}\right)$ that is consistent with the mean organic carbon flux measured from 32 sediment traps (16 mmol/ $/ \mathrm{m}^{2} / \mathrm{d}$; Silverberg et al., 1987).

g. Data from Silverberg et al. (2000) except for depth and bottom water oxygen (Gilbert et al., 2005) and the U accumulation rate (Sundby et al., 2004). The mass accumulation rate at station 4 is consistent between Smith and Schafer (1999) and Silverberg et al. (2000), but variable at station 2 where Silverberg et al. (2000) suggests a lower value relative to Smith and Schafer (1999).

h. Data from Morford et al. (2007) except for the organic carbon concentration, which is based on the average concentration below $10 \mathrm{~cm}$ from four sediment cores collected in 2002 and 2003 (Kalnejais, 2005).

j. Data from Morford et al. (submitted) except for the average organic carbon concentration (McNichol et al., 1988).

k. The mass accumulation rate is from Alperin et al. (2002) and Thomas et al. (2002). The organic carbon rain rate is the sum of the carbon burial and oxidation rates.

m. This work, except for the mass accumulation rate (Anderson et al., 1994).

$\mathrm{n}$. The mass accumulation rate and the organic carbon burial rate are from nearby locations at similar water depths (Bothner et al., 1981). The organic carbon concentration is based on the average concentration below $10 \mathrm{~cm}$ from sediment cores (Bothner et al., 1981; Anderson et al., 1988). 


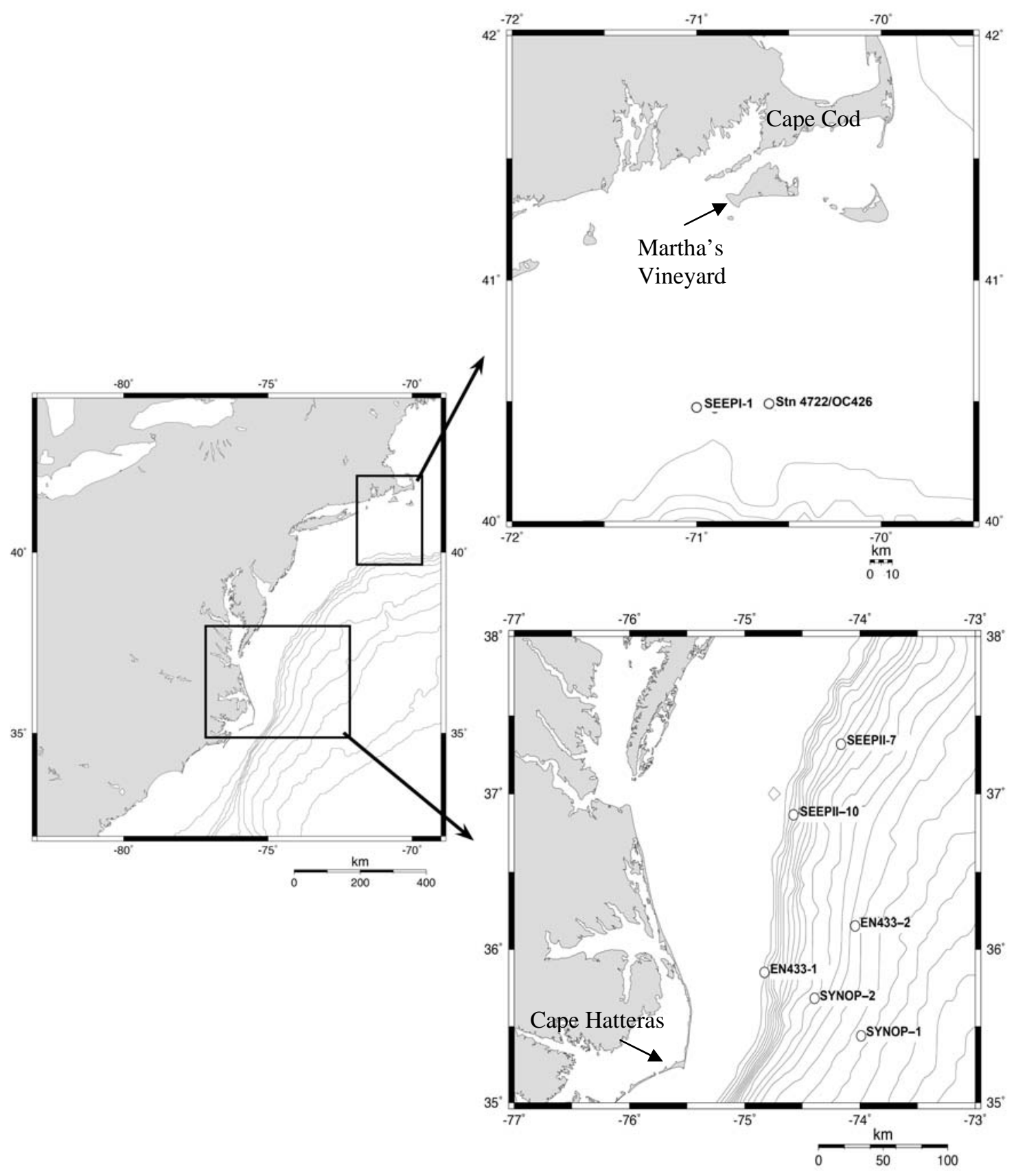

Figure 1. 
(A)

$\mathrm{O}_{2}(\mu \mathrm{mol} / \mathrm{L}) \quad \mathrm{NO}_{3}+\mathrm{NO}_{2}(\mu \mathrm{mol} / \mathrm{L})$
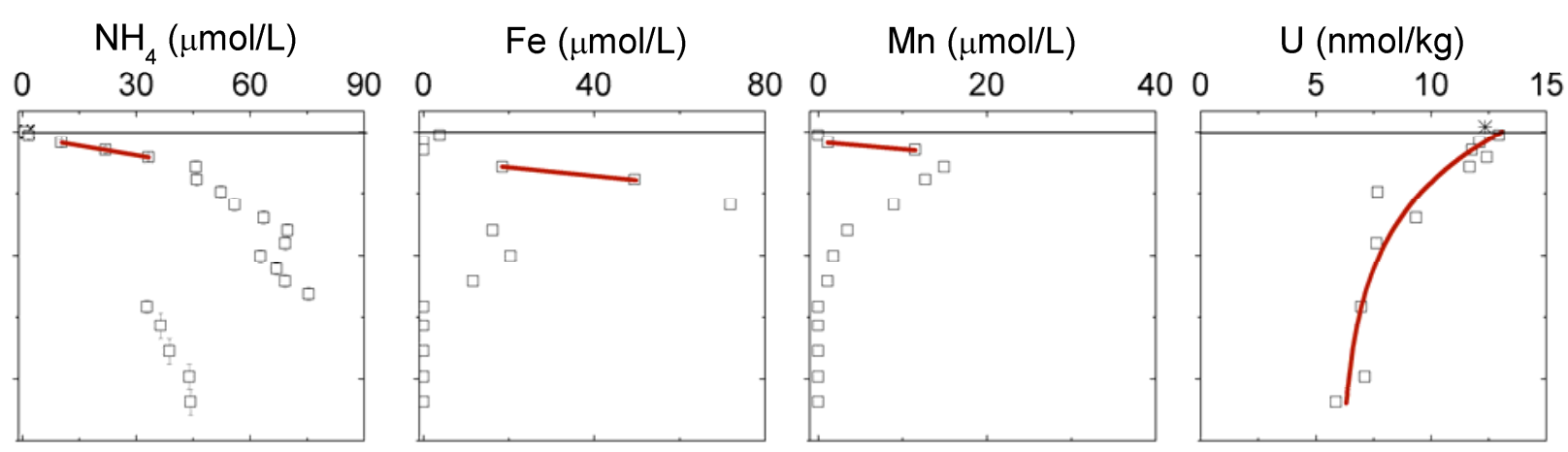

(B)
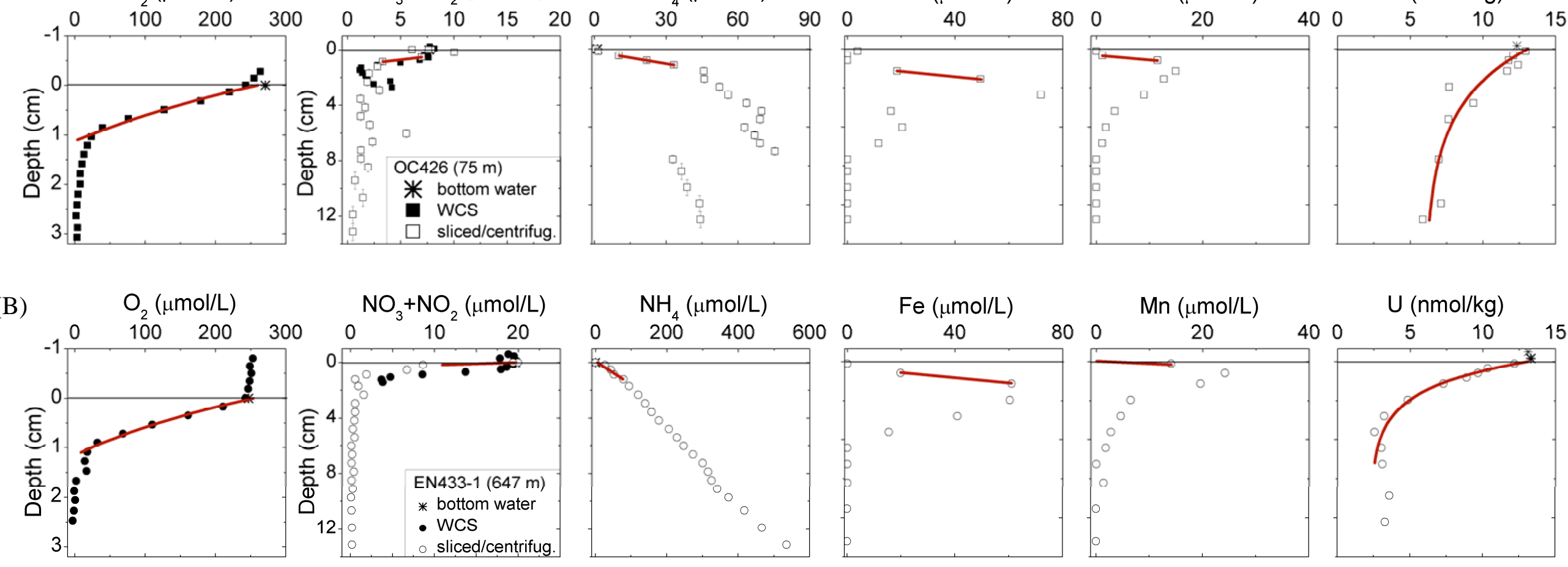

(C)
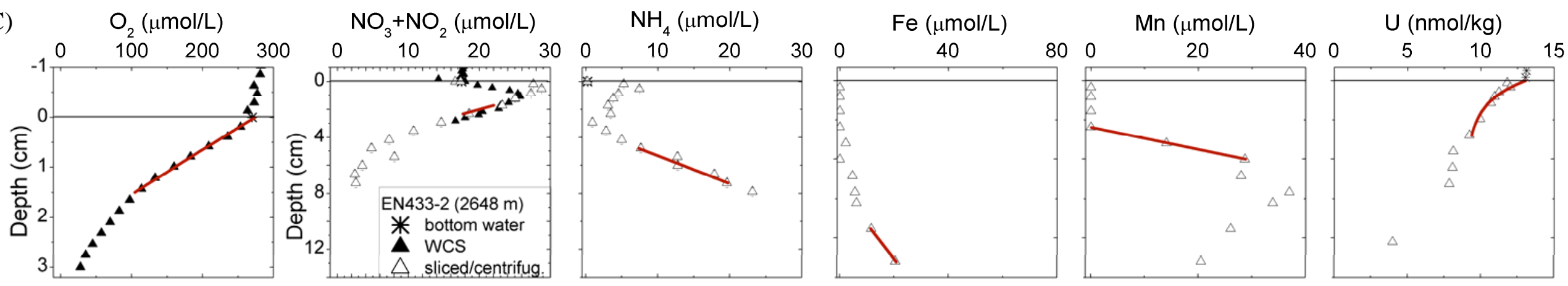

Figure 2. 

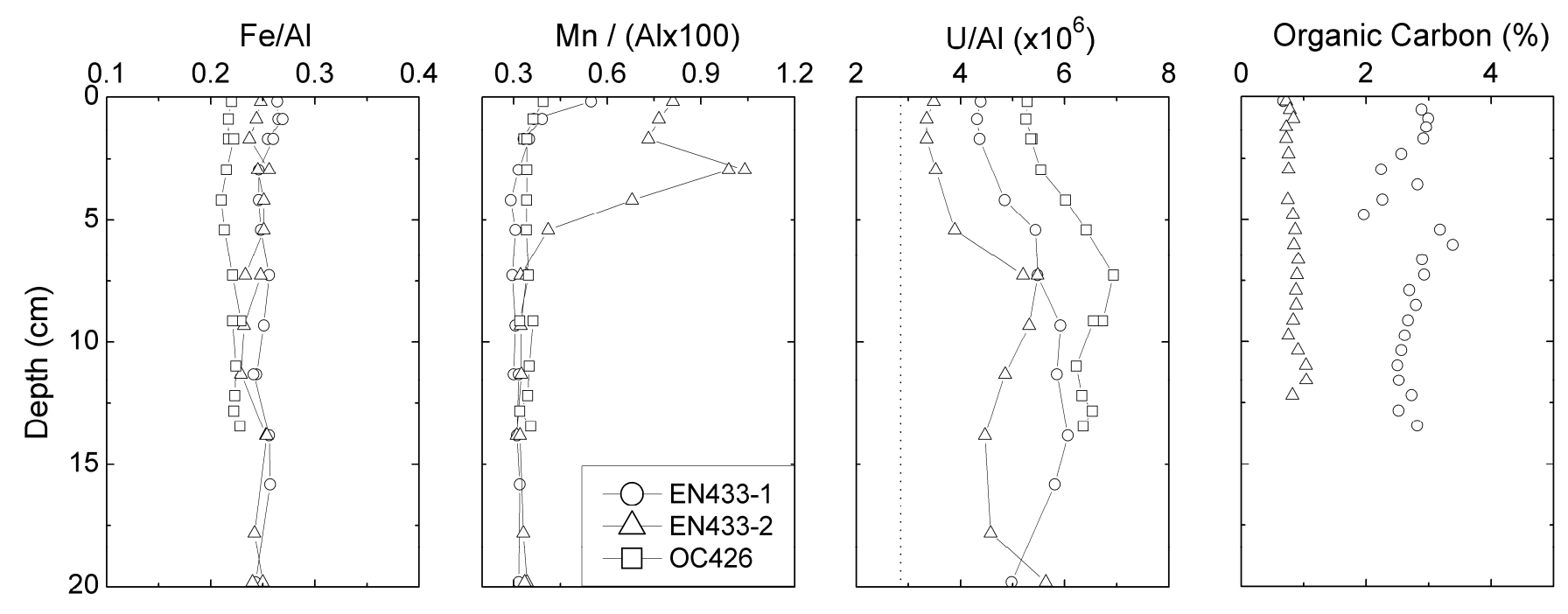

Figure 3. 
(A)

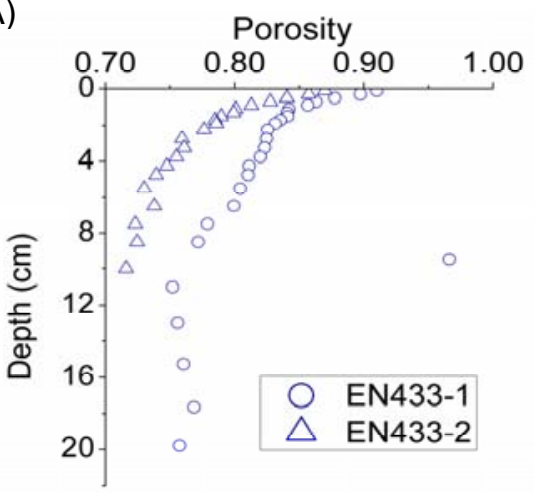

(C)

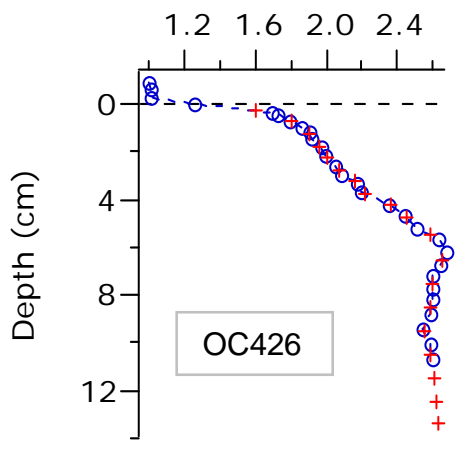

(B)

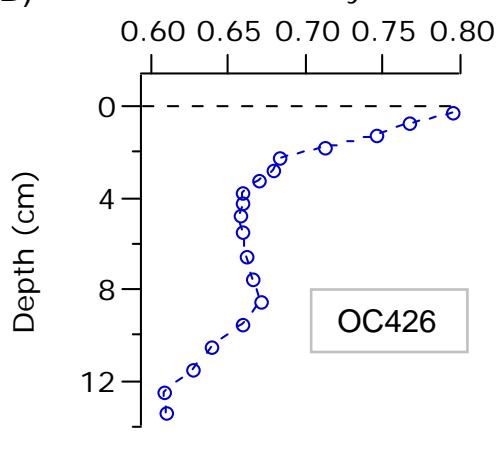

(D)

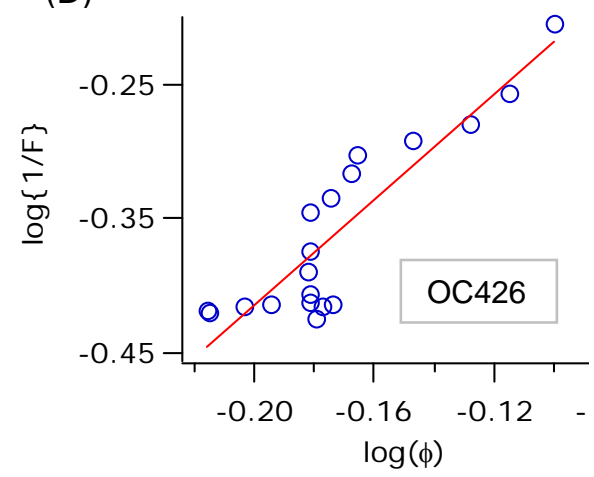

Figure 4. 

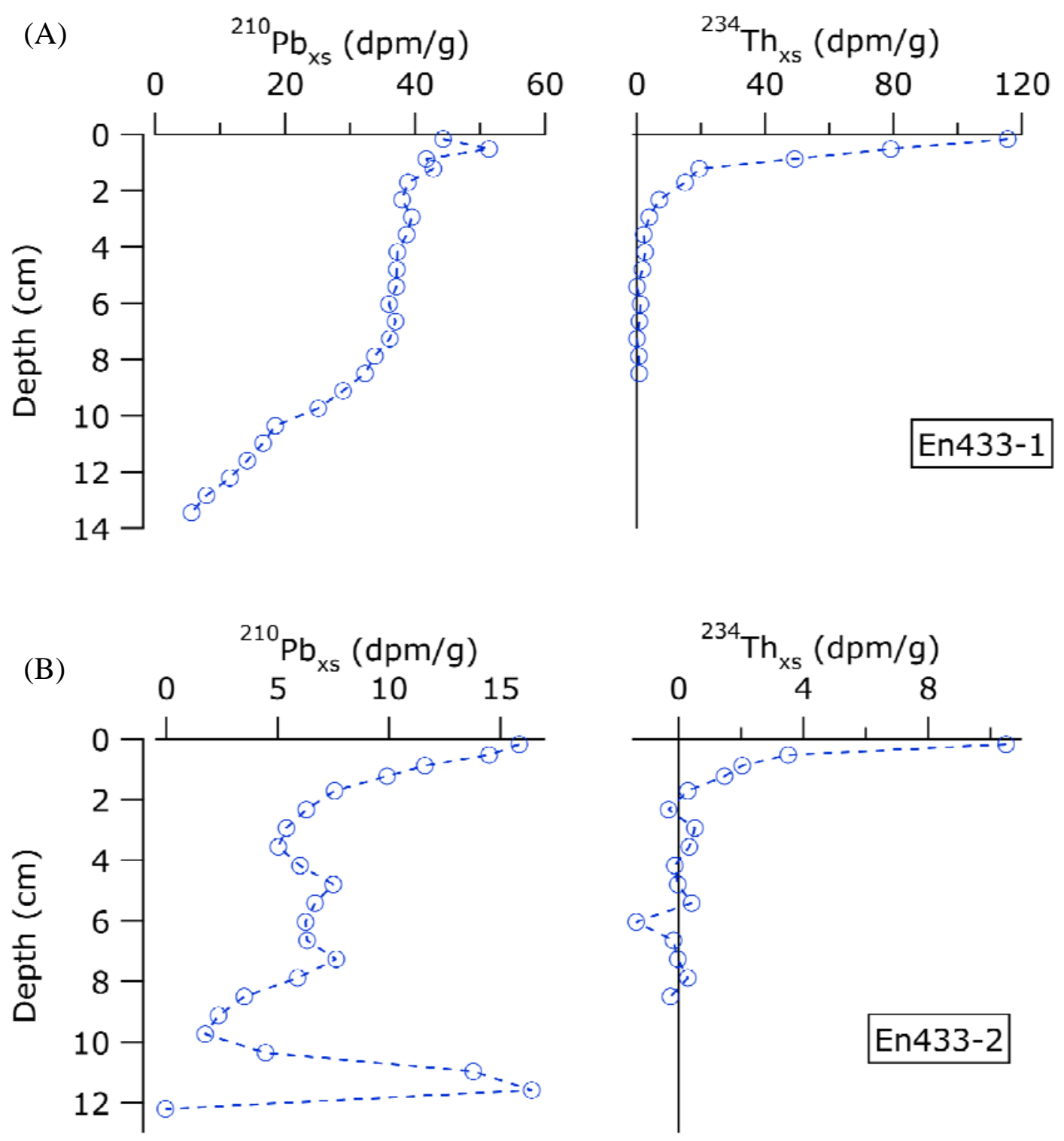

Figure 5. 
(A)

(B)
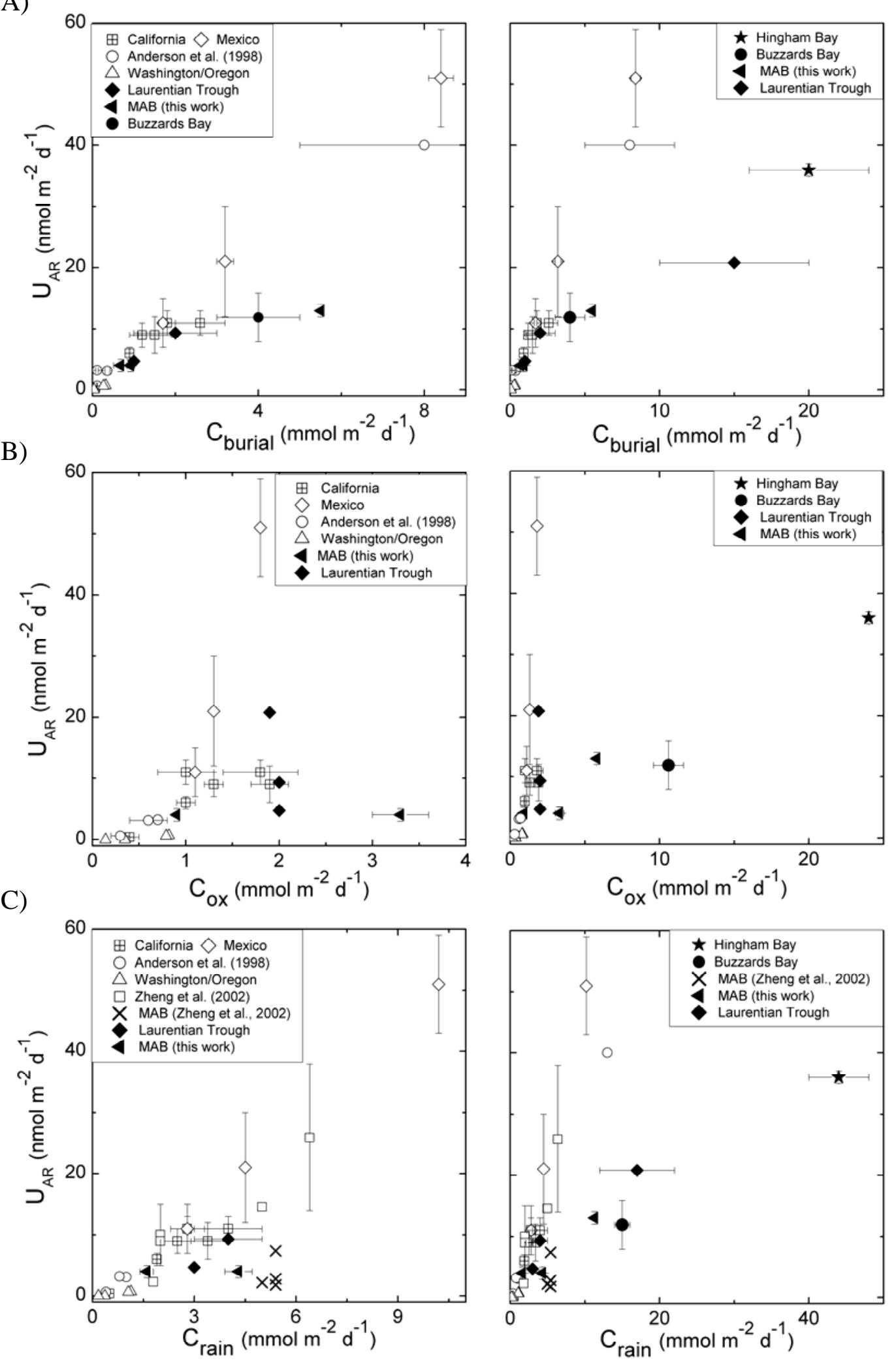

Figure 6. 


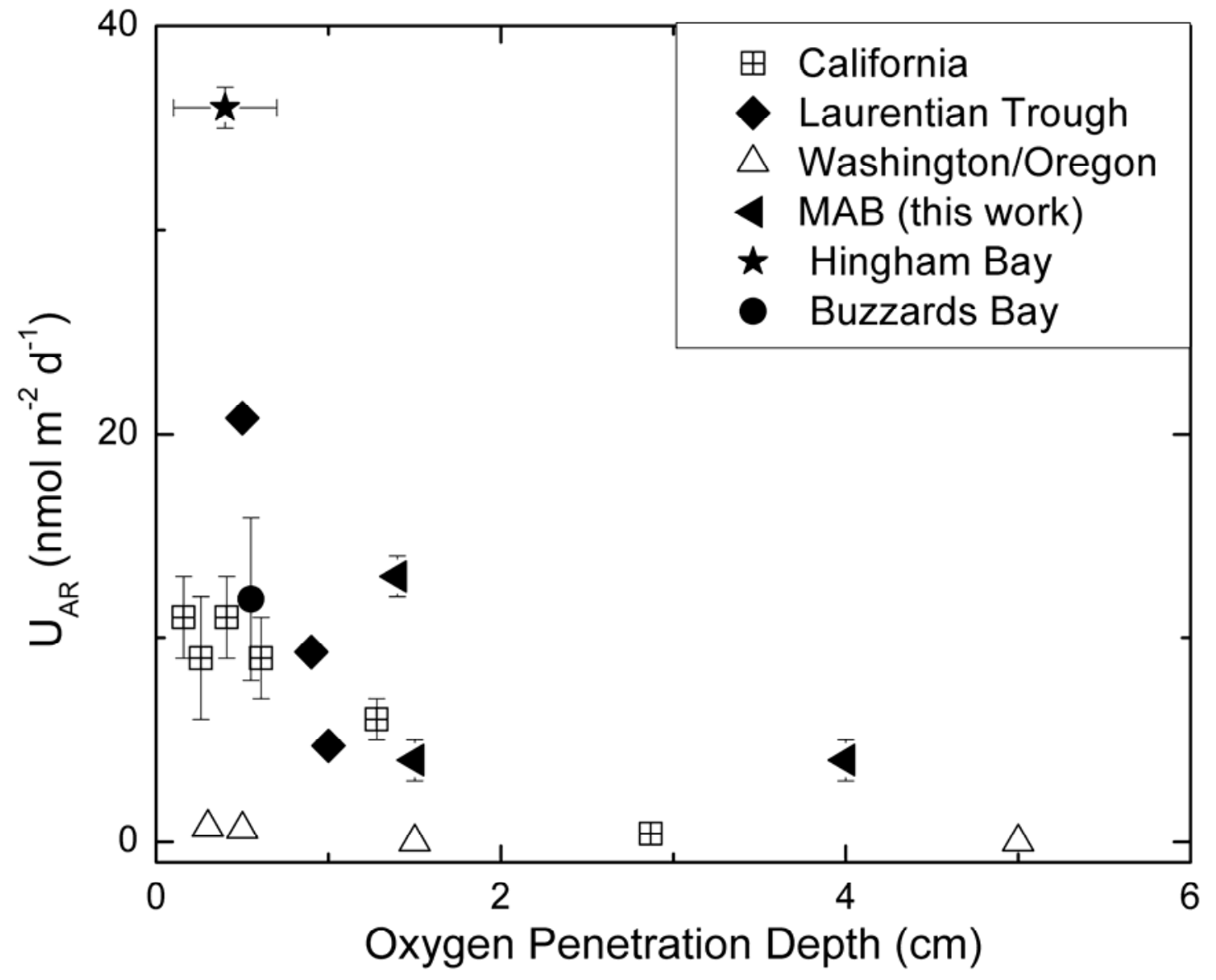

Figure 7. 